NBER WORKING PAPER SERIES

\title{
INVESTOR BEHAVIOR AND THE PURCHASE OF COMPANY STOCK IN 401(K) PLANS - THE IMPORTANCE OF PLAN DESIGN
}

\author{
Nellie Liang \\ Scott Weisbenner \\ Working Paper 9131 \\ http://www.nber.org/papers/w9131 \\ NATIONAL BUREAU OF ECONOMIC RESEARCH \\ 1050 Massachusetts Avenue \\ Cambridge, MA 02138 \\ September 2002
}

The views expressed in this paper are those of the authors and not necessarily those of the Federal Reserve Board or the National Bureau of Economic Research. We thank Darrell Cohen, Paul Harrison, George Pennacchi, Allen Poteshman, Mike Weisbach, and participants at seminars at the Federal Reserve Board and University of Illinois for helpful comments, and Eric Richards, Robert Paul, and Aldo Rosas for exceptional research assistance.

(c) 2002 by Nellie Liang and Scott Weisbenner. All rights reserved. Short sections of text, not to exceed two paragraphs, may be quoted without explicit permission provided that full credit, including $\odot$ notice, is given to the source. 
Investor Behavior and the Purchase of Company Stock in 401 (k) Plans -

The Importance of Plan Design

Nellie Liang and Scott Weisbenner

NBER Working Paper No. 9131

September 2002

JEL No. G11, J30, J32

\section{$\underline{\text { ABSTRACT }}$}

Using panel data for nearly 1,000 companies during 1991 to 2000, this paper documents that the average share of participant's discretionary 401(k) contributions in company stock was almost 20 percent, and then relates this share to plan design features and firm financial characteristics. We find that the number of investment alternatives offered, $n$, and whether the company requires some of the match to be in company stock are key factors of the share of total contributions in company stock. We cannot reject the hypothesis that participants invest $1 / n$ of their contributions in company stock. In addition, participants do not offset an employer match in company stock with a smaller share of their own contributions to company stock, contrary to efficient diversification. Workers also appear to view other plan restrictions as providing cues about the desirability of purchasing company stock. Thus, plan design is very important in determining the share of $401(\mathrm{k})$ assets in company stock.

Nellie Liang

Federal Reserve Board

Capital Markets, Stop 89

$20^{\text {th }}$ and C Sts. NW

Washington, DC 20551

Phone: (202) 452-2918

e-mail: nliang@frb.gov
Scott Weisbenner

University of Illinois - Department of Finance

304C David Kinley Hall, MC-706

1407 W. Gregory Drive

Urbana, IL 61801

phone: (217) 333-0872, fax: (217) 244-9867

e-mail: weisbenn@uiuc.edu

and NBER 


\section{Introduction}

The dramatic collapse of Enron has led to heightened scrutiny of the structure of 401(k) plans and how participants make their investment decisions. Currently, about 45 million workers participate in a 401(k)-type plan, and aggregate assets of these plans totaled \$1.97 trillion in 2001, surpassing assets in traditional defined benefit pension plans. The trend away from defined benefit towards 401(k)-type plans has forced employees to assume greater responsibility for their retirement savings, requiring them to make decisions about how much to save and how to save it. In addition to traditional investment choices of money market, broad bond and equity funds, employees are often also given the option to invest their $401(\mathrm{k})$ contributions in company stock. The Profit Sharing Contribution / 401(k) Council of America reports that company stock is offered as an investment option in 72 percent of retirement plans with more than 5,000 participants.

Markowitz (1952), Sharpe (1964), and Lintner (1965) would predict that employees would forego investments in their own company's stock in favor of diversified portfolio. Indeed, when one considers the human capital and other forms of wealth many workers already have tied to their firm, investment in company stock would seem an inefficient choice. However, many workers do not have well-diversified retirement plan portfolios. At Enron, for example 62 percent of 401(k) assets at year-end 2000 were held in company stock. Part of the high concentration reflected that the company match was made in Enron shares, but Enron employees were also allocating a large fraction of their

\footnotetext{
${ }^{1}$ Among plans with 1,000-4,999 participants, 40 percent offer company stock as an investment option. The smaller percentage offering company stock likely reflects that many of the smaller plans are offered by private firms.
} 
own, discretionary contributions to company stock as well.

Such a high concentration of new contributions and existing holdings of retirement assets in company stock is not unique to Enron. For example, at General Electric, Home Depot, and Pfizer, more than 75 cents of every dollar in defined contribution plan assets is held in company stock. At the other end of the spectrum, less than one-eighth of $401(\mathrm{k})$ assets are in company stock at Dell, Halliburton, and Xerox. More broadly, several recent studies estimate that among plans that offer company stock as an investment option, the fraction of assets held in company stock totaled between 30 and 40 percent in recent years, with a large range across companies.

Holding a portfolio tilted towards company stock is costly to employees, as they are exposed to firm-specific risk that could have been diversified away. This lack of diversification will result in an ex ante loss in welfare, and as Meulbrook (2002) illustrates, the cost to workers can be substantial. To help understand why employees invest in company stock and the variation in contributions to company stock across firms, this paper examines factors that influence the investment decisions made by participants in retirement plans. The paper first documents that the average share of participants' discretionary 401(k) contributions in company stock was 19 percent at a sample of 994 publicly-traded companies during 1991 to 2000. We then examine how this share is related to the design of the $401(\mathrm{k})$ plan and financial characteristics of the firm. In particular, we examine whether purchases can be explained by the number of investment

\footnotetext{
${ }^{2}$ In 1998, the last date for which detailed contribution data are available in the company's 11-k filing, employees allocated 20 percent of their own contributions to company stock purchases.

${ }^{3}$ For example, see studies by Holden and VanDerhei (2001) and the Profit Sharing / 401(k) Council of America.
} 
options available, whether there are constraints on investment choices, whether the company matches with company stock, previous stock returns, and other firm financial characteristics. The primary contribution of this paper is to document how company stock purchases are related to the features of the $401(\mathrm{k})$ plan.

Two recent papers have focused specifically on how company stock purchases in 401(k) plans respond to firm performance. Benartzi (2001) looks at employee decisions to purchase company stock in 401(k) plans at $136 \mathrm{~S} \& \mathrm{P} 500$ companies in 1993, and finds greater discretionary purchases of company stock when the company makes its matching contribution in company stock, and when previous company stock returns have been high. He attributes this pattern to two factors: a tendency for investors to view employer stock contributions as an explicit endorsement of the stock, and a tendency for investors to extrapolate forward previous returns. This tendency to extrapolate forward past returns is consistent with "representativeness" theory (Tversky and Kahneman, 1974), in which people overestimate the probability that stock returns in the next period will be high if previous returns were high. Sengmuller (2001) examines employee purchases of company stock in retirement plans for a panel of 239 firms in the S\&P 500 index at some point between 1994 and 1998. Similar to Benartzi, he finds that past returns are a strong predictor of purchases of company stock, but the relationship is weaker after 1993.

We extend this research in a number of ways by focusing on plan characteristics, in addition to firm performance, as determinants of company stock purchases. First, we examine how the number of investment alternatives offered in 401(k) plans affects the purchase of company stock. If participants simply follow a naïve $1 / n$ diversification rule, where $\mathrm{n}$ represents the number of investment options, fewer investment alternatives 
would lead to higher purchases of company stock. Second, our time series data also allow us to examine how purchases of company stock respond to the introduction of more investment alternatives. For example, as a company increases the number of alternatives from 5 to 8 , does the allocation to company stock decline, and is the effect immediate? We also consider carefully other plan features, such as whether the plan imposes minimum or maximum limits on purchases of company stock. Third, we examine, like Benartzi (2001) and Sengmuller (2001), whether purchases of company stock are higher when the employer matches in company stock. However, our time series data also permit us to examine how purchases respond to the introduction of employer matches in company stock, alleviating the interpretation problem that the positive correlation observed in the cross-section could reflect an underlying employee preference for company stock in firms that offer a match in stock. Fourth, we use a considerably larger data set than previous studies. Our sample is based on 11-k data filed by publicly-traded companies describing company stock purchases from 1991 to 2000 . Our sample has 3,412 observations covering 994 different firms; the years with the greatest number of observations, more than 600 each, are 1997 and 1998.

We find that the most important determinant of the share of contributions allocated to company stock is the number of investment options, $\mathrm{n}$, offered by the plan. We cannot reject that employees follow a naïve $1 / \mathrm{n}$ diversification rule, investing $1 / \mathrm{n}$ of their contributions in company stock. This result is consistent with Benartzi and Thaler (2001) that find that the share of 401(k) assets in equities is largely determined by the number of equity-type investment options offered. In addition, we find that employees do not offset employer matches in company stock, leading to a substantial concentration 
of 401(k) assets in company stock. Finally, we find evidence that employees appear to interpret an employer match in company stock as the provision of implicit investment advice, and increase their purchases of company stock accordingly. Additional evidence on the effects of other restrictions, such as minimum or maximum limits on company stock purchases, suggest that workers take investment cues from restrictions present in the plan, also supportive of an endorsement effect.

These results indicate that companies have very large effects on 401(k) asset holdings through the choice of some key plan features. So, we then turn the question around - what determines the number of alternatives that a plan offers, and what determines whether companies match with company stock? One specific area we address is whether these plan design features are affected by past firm performance, and thus whether the relationship we find between company stock purchases and plan features is merely reflecting past firm performance. We also examine whether the decision to match in company stock could be driven by the desire of firms to reduce future taxes.

Understanding what factors determine the decision to purchase company stock in 401(k) plans is important, as investing a large fraction of retirement savings in company stock can impose substantially large ex ante welfare costs on employees if its leads to lack of diversification. Our analysis will also be of use in evaluating the proposals that have been made, in the wake of Enron's dramatic failure, to establish new regulations for participant investments in retirement savings plans. Section II describes our sample and provides summary statistics. Section III discusses what the previous literature, both from finance and psychology, suggest may motivate the purchase of company stock, and then presents the empirical analysis of company stock purchases in retirement plans. Given 
the importance of plan design, we examine what determines important plan features such as the number of options offered and match policy in Section IV. A summary of our findings and public policy implications follows in Section V.

\section{Data and Sample Characteristics}

Our primary data source for investments in defined contribution plans is the 11-k form that some plans are required to file with the SEC. This form is required of plans for which the investment option to purchase company stock is deemed an offering of securities. In general, companies that offer participants the choice to purchase company stock with their own contributions and that issue shares for the plan, rather than purchase shares on the open market, are required to file an 11-k. Data on plans that exclusively buy shares on the open market are not publicly available, so our results may or may not generalize to this population. If the employer contribution is in company stock, but the plan does not allow employees to purchase stock, it would generally not be deemed an offer of securities, and thus the plan would not be required to file. In our discussion with SEC staff, the 11-k obligation is almost a fact and circumstance determination, and the company has an obligation to determine whether it needs to file. Because 401(k) plans are subject to ERISA, the information provided on the $11-\mathrm{k}$ is in accordance with ERISA reporting guidelines. In 1999, there was a change in ERISA reporting requirements that led to fewer companies reporting contributions by asset category, leaving us with contribution data for far fewer plans in 1999 and 2000 than in 1998.

The data we collect from 11-k filings include total participant contributions, participant contributions allocated to company stock, employer contributions, employer 
contribution in the form of company stock, total plan assets, company stock assets, number of investment alternatives, and descriptions of limits on purchases of company stock. As in Benartzi (2001), we collect data for the largest plan at each company. Information on stock prices and standard deviation of returns are from the Center for Research in Security Prices (CRSP) database. Other firm financial information, including market-to-book ratios, assets, cash flow (net income plus depreciation), and employees are from Compustat.

Starting with all U.S. firms listed in Compustat any year from 1993 to 1999, we identify firms that filed an 11-k at least once during 1994 to 2001 (table 1). ${ }^{⿴}$ We were able to hand-collect data for 994 companies, yielding 3,412 firm-year observations. Most of the data are in the period 1993 to 1998 . On average, there are 3.4 observations per firm, with 41 percent of the firms with 2 observations or less and 59 percent of the firms with 3 observations or more. The sample represents a broad cross-section of industries (table 2), with the largest concentrations in the financial and technology sector. As noted in the last line of the table, only about one-fourth of our sample was ever a member of the S\&P 500. Our sample is considerably larger than samples for Benartzi (2001) or Sengmuller (2001), which included only firms that were a member of the S\&P 500 in 1993 and at any time during 1994-98, respectively.

To further characterize our sample, we focus on firms in the sample in 1998, one of the more recent years with the largest number of firms. Almost one-half of the firms were not in the broad S\&P 1500 index in 1998, indicating that the companies are

\footnotetext{
${ }^{4}$ 11-k filings are available on the SEC's Edgar website starting in 1994. The 1994 filing will report plan activity during 1993. Some firms will report not only plan activity during the past year, but plan activity over the past three years. Thus, we have 190 observations for 1992 and 51 observations for 1991.
} 
considerably smaller than those examined in previous studies (table 3a). As compared to firms in the S\&P 1500, and all publicly-traded firms, there are somewhat fewer technology firms. As expected, the firms in our sample are smaller, measured by both assets and employees, and have slightly lower market-to-book ratios than S\&P 1500 firms (table 3b). As compared to all public companies, however, the firms in our sample are larger.

Recall that, in general, companies that issue shares for their retirement plan, rather than purchase shares on the open market, are required to file an 11-k. This raises the potential that the sample could be biased to firms that do not repurchase stock at all. However, as shown in the final row of table $3 b$, roughly half of the firms in the sample repurchased stock in 1998 (just evidently not in conjunction with their retirement plan). The share repurchase yield (an estimate of the fraction of shares repurchased) for the sample was 1.8 percent in 1998, similar to the yield for the S\&P 1500.

We also compare our sample of plans to those at publicly-traded firms as reported on Form 5500 filed with the Department of Labor. ${ }^{\text {E }}$ In the aggregate, for our sample of the largest plans at 667 companies in 1998, total plan assets were $\$ 274$ billion, representing about 40 percent of the $\$ 698$ billion in plan assets at all publicly-traded companies (table 3c). Total contributions by participant and company for our sample totaled $\$ 15.5$ billion, as compared with $\$ 49.2$ billion for publicly-traded firms.

Estimates from the Department of Labor for 1998 for all US companies, public and private, show $\$ 1.65$ trillion in assets and $\$ 135$ billion in contributions.

For our sample of 667 companies in 1998, company stock in aggregate totaled

\footnotetext{
${ }^{5}$ Publicly-traded companies on the DOL Form 5500 data set were identified by whether they had a CUSIP, and by matching EINs with those in Compustat.
} 
$\$ 102$ billion, representing 37 percent of plan assets. Purchases of company stock as a percent of total participant contributions are 24 percent. These averages are similar to those in the samples analyzed by Benartzi (2001) and Sengmuller (2001). ${ }^{\text {G }}$ The Department of Labor 5500 data indicate that $\$ 273$ billion of $\$ 1.65$ trillion of $401(\mathrm{k})$-type assets, or one-sixth, was held in company stock, likely because smaller, privately-held firms do not offer company stock. The estimated share of defined contribution plan assets held in company stock at all public firms is 39 percent, similar to the share for our sample.

\section{Empirical Analysis of Purchases of Company Stock}

\section{A. 401(k) Plan Design}

Table 4 summarizes features of the 401(k) plans that could affect the participants' purchases of company stock. As suggested by Benartzi and Thaler (2001), one of the most important features that guide employee contributions is the number of investment alternatives. For our sample, the average number of investment options offered is 7.5, with a $25^{\text {th }}$ and $75^{\text {th }}$ percentile range of 5 to 9 . These figures are similar to the 170 plans studied in Benartzi and Thaler (2001) that offered on average 6.8 investment options in 1996. By sample construction, company stock is one of those investment options. For six percent of the firm-year observations, company stock was offered as an option in the plan for the first time.

A few companies have explicit guidelines regarding company stock purchases.

\footnotetext{
${ }^{6}$ Benartzi found that company stock represented 33 percent of assets, and Sengmuller found a ratio of 35 percent in 1998. Based on contributions, Benartzi finds that 24 percent of participant contributions went to company stock and Sengmuller reports 24.5 percent in 1998.
} 
For about 4 percent of the firm-year observations, there is a ceiling on how much of the employee contribution can be made in company stock, ranging from 10 to 50 percent of total contributions. Among plans with a maximum restriction, about two-fifths have a ceiling of $50 \%$, and an additional three-tenths have a ceiling of $25 \%$. Less than one percent of firms put a floor on purchases of company stock. In addition, about one percent of firms provide an incentive to purchase company stock, through a discount or larger employer match.

Employers made contributions to the retirement plan in 94 percent of our firmyear observations, similar to other studies that find that nearly all employers offer a match (e.g., Holden and VanDerhei, 2001). In our sample, 48 percent of employers that granted a match required that at least part of the match be in company stock, with nearly two-fifths of the firms requiring that the entire amount of employer contributions be in company stock. Only about 2 percent stipulate that some part of the employer match not be invested in company stock.

The remainder of this section examines how these features affect purchases of company stock, starting with the most prominent features, the number of investment options and restrictions on the employer match.

\section{B. Previous literature and the effect of the number of investment alternatives}

This section tests whether the number of options offered in the 401(k) plan influences investment in company stock. The principal hypotheses we examine are diversification and familiarity. The fact that the participant already receives income from the firm and has a substantial human capital investment in the firm a priori nearly rejects the hypothesis that any company stock purchases could be consistent with the efficient 
diversification outlined by Markowitz (1952), Sharpe (1964), and Lintner (1965). Given their wealth already tied to the firm, efficient portfolio theory would suggest that employees should invest minimal, if any, contributions to company stock to avoid ex ante welfare costs due to the lack of portfolio diversification.

Benartzi and Thaler (2001) provide evidence of naïve diversification behavior. They find that the share of $401(\mathrm{k})$ assets held in equities is largely determined by the number of equity-type investment options offered, consistent with participants following a naive $1 / \mathrm{n}$ diversification rule, in which assets are divided equally among the $n$ investment options offered in the retirement savings plan. Goetzmann and Kumar (2001) also argue that investors use naive diversification rules in their equity investment accounts. Specifically, investors will hold numerous stocks but they fail to take into account the correlations among the stocks they hold, and thus are under-diversified, perhaps because of high costs of acquiring information to make more informed decisions.

There is some evidence, however, suggesting that participants view company stock as an asset separate from other equities. Benartzi and Thaler (2001) find that when plans do not offer company stock as an option, the assets are split about equally between equity and fixed-income securities; but, among plans that offer company stock, participants do not reduce non-company equity securities - instead, company stock accounts for 42 percent of assets, and the remaining 58 percent is split roughly evenly between other equities and fixed income securities.

Investing in company stock may be viewed differently from investing in other equities for several reasons. The distinction could owe to pressures that a participant may feel from the firm or colleagues to purchase stock and increase share ownership, or that 
the investment is considered to be less risky because of familiarity with the company. Heath and Tversky (1991) and Langer (1975) present evidence that people suffer from an "illusion of control" and behave as though familiar gambles are less risky than unfamiliar gambles, even when they assign identical probabilities of success to the two gambles. Heath and Tversky (1991) further conclude that this tendency to bet on the familiar "might also help explain why investors are sometimes willing to forego the advantage of diversification and concentrate on a small number of companies which they are presumably familiar."

There is much evidence of investing in the familiar "home team," perhaps because investors perceive familiarity to imply less risk. Huberman (2001), using data on the ownership of Regional Bell Operating Companies, finds that investors have a strong tendency to invest in stocks with which they are geographically proximate and familiar. The unwillingness of investors to diversify internationally - French and Poterba (1991) is one of many studies to document the home country bias - is another classic example of investing in the familiar. Coval and Moskowitz (1999) find that U.S. investment managers exhibit a strong preference for locally headquartered firms in their portfolios.

In the context of a 401(k) plan, a preference for investing in the familiar would translate into purchases of own company stock, which is likely the most familiar investment option. Indeed, annual surveys by John Hancock Financial Services regularly find that participants view company stock as the most familiar investment option in their retirement plan. Given their familiarity with company stock, it is thus not too surprising that workers tend to underestimate its risk. As figure 1 shows, participants surveyed by

\footnotetext{
${ }^{7}$ Investing in the familiar may also be driven by asymmetric information between local and nonlocal investors, as Coval and Moskowitz suggest for U.S. investment managers.
} 
Vanguard view company stock as safer than a diversified portfolio of stocks as well as the stock of any other individual company. Further, Benartzi (2001) finds that investors overestimate the likelihood that company stock will outperform the overall stock market.

These results suggest that employees may view company stock in its own category separate from other equities, and thus may not adopt the simple $1 / \mathrm{n}$ diversification rule for purchases of company stock. If workers adopt the $1 / \mathrm{n}$ rule, then the addition of investment options should reduce purchases of company stock. However, if the purchase of company stock is driven by the familiarity hypothesis, then adding more unfamiliar investment options will likely not affect company stock purchases very much. Since the additional options will likely be less familiar to the employee than company stock, the additional options will likely not siphon contributions away from firm stock.

Because we have annual data on plan contributions, we are able to test implications of the naïve diversification and familiarity hypotheses. Findings by Benartzi and Thaler (2001) are based on asset holdings, rather than new flows (i.e., contributions into the plan). Using data on asset holdings could obscure the strength of the relationship between options offered and allocation decisions. The allocation of assets may just reflect differences in past returns since participants are slow to rebalance their portfolios (Samuelson and Zeckhauser, 1988). Our data on flows to 401(k) plans permit us to directly observe the underlying relationship between plan attributes and subsequent investment decisions.

The distribution of the dependent variable -- the fraction of participant 
contributions in company stock -- is shown in table 5. This variable represents the fraction of total firm-wide employee contributions allocated to company stock. For our sample, the average fraction of participant contributions invested in company stock is 19 percent (median 14 percent), with a standard deviation of 17 percent. In interpreting our results, we often use this measure to represent the investment decision of the "average" employee. Unlike the grant of employee stock options, which are highly skewed towards upper management, nearly all employees are eligible to participate in 401(k) plans. Moreover, contributions are more evenly distributed across the workforce, since taxdeferred employee contributions are capped (e.g., the limit was $\$ 10,000$ per employee in 1998), and there are limits relating to participation by highly compensated employees relative to other employees so as to preserve the tax-exempt status of the plan.

To determine the importance of the number of investment options, we first tabulate the average fraction of participant contributions invested in company stock by the number of investment options offered (table 6). As shown in more detail than in table 4 , the average number of investment alternatives offered in our sample is 7.5 , the median is 7 , and the $1^{\text {st }}$ to $99^{\text {th }}$ percentile range is 3 to 18 . Since we have a panel data set, multiple observations from the same firm over time are used in calculating the averages. Thus, we allow for within-firm correlation when calculating the standard error, as we do for all pooled regressions throughout the paper.

We find a very striking and strong relationship between the number of investment

\footnotetext{
${ }^{8}$ This variable has been adjusted for the 92 observations in which company stock was available as an investment option for only part of the year. For example, if company stock was only available for a quarter of the year, then total employee contributions for the year will be divided by four when calculating the share of contributions allocated to company stock. This adjustment is made to reflect that company stock was a possible choice for only one fourth of the year.
} 
options and the fraction of company stock purchases: The purchase of company stock monotonically declines with the number of investment options offered. If the plan offers two investment options (company stock and some other asset), the average fraction of company stock purchased is 59 percent; if the plan offers three options, the fraction is 36 percent; if the plan offers four options, the fraction is 26 percent; and so on until the share levels out at 13 percent, when plan offerings include 10 or more options. For the firms that offer 2 through 6 options, we cannot reject that employees adopt a $1 / n$ investment strategy for company stock. We obtain a similar pattern of results when looking at the median share of participant contributions allocated to company stock across the number of investment options.

We next run a regression of the fraction of employee contributions in company stock on $1 / \mathrm{n}$, for individual years of the sample and the full sample. We specify the number of investment alternatives as $1 / \mathrm{n}$, not $\mathrm{n}$, because we would expect a nonlinear relationship between the number of investment alternatives and allocations to company stock. If the naïve diversification hypothesis is true, an additional option should reduce contributions to company stock more if the plan initially had only three options than if it had ten options. Indeed, a coefficient of one on the $1 / \mathrm{n}$ variable would suggest that workers, on average, adopt a naïve diversification rule for company stock. In contrast, the familiarity hypothesis would predict a coefficient of less than one, and likely close to zero. Recall under this hypothesis, employees will tend to allocate contributions to company stock because of its familiarity, and because additional options will likely be less familiar to the employee, the additional options will likely not reduce contributions to company stock. 
Results are reported for the years 1993 to 1998 and the pooled sample from 19912000 (table 7). As suggested by our earlier tabulations, $1 / \mathrm{n}$ is a very significant indicator of employee purchases of company stock. For each year and the pooled sample, the coefficients are close to one, and we cannot reject that the coefficient equals one for any of the regressions. ${ }^{6}$ These estimates imply that when the typical plan offers 5 investment options, for example, the expected share of participant contributions in company stock is 20 percent. We also find that $1 / \mathrm{n}$ by itself explains roughly 10 percent of the variation in the dependent variable. ${ }^{10}$ A direct interpretation of these results is that plans can substantially reduce the share of company stock purchases simply by increasing the number of investment options. These results provide strong support for a naive diversification heuristic.

A possible objection to this interpretation is that the number of investment options might reflect the demands of participants, and that the empirical associations we document simply reflect that employees with preferences for many investment options work for companies that offer 401(k) plans with that design. For example, firms with less risk-averse workers that want to invest in company stock may not feel the need to offer many other investment options. We would then observe a negative correlation between the number of options and the investment in company stock, just as predicted by the naïve diversification hypothesis, but the interpretation of the correlation would be different.

\footnotetext{
${ }^{9}$ We obtain similar coefficient estimates, statistically indistinguishable from one, when we weight observations by the number of firm employees and the total amount of employee contributions.

${ }^{10} \mathrm{We}$ also note that once we control for the number of investment options offered, the estimated constant in the regression is not statistically different from zero in most of the single-year regressions, and while significant in the pooled regression, its value is fairly close to zero.
} 
To address this issue, we employ the panel nature of our data set to estimate a fixed-effects regression, which allows us to characterize the change in employee purchases of company stock to the change in the number of options available for a given firm. As shown in the last row of table 7 , the coefficient estimate on $1 / \mathrm{n}$ is .27 and significant, suggesting that when the number of investment options increases from 5 to 10, participants on average do not fully adjust their purchases of company stock from $1 / 5$ to $1 / 10$ (20 percent to 10 percent), but only adjust one-quarter of the way. Thus, our results suggest that participants change their allocations in accord with a naive $1 / \mathrm{n}$ diversification approach, but a full adjustment is not immediate, consistent with documented behavior of investor inertia.

To explore this adjustment process further, we regress the change in the fraction of employee contributions in company stock on the change in the number of options offered. The regressions include 2,418 firm-year observations for which data on the contributions are available for at least two consecutive years. Of these, 667 increased the number of options offered during a one-year period. ${ }^{-1}$ As shown in column 1 of table 8 , the estimated coefficient on the change in $1 / \mathrm{n}$ in the concurrent period is .18 and significant, suggesting that some (but clearly far from all) participants immediately make an adjustment to their share of contributions going to company stock when the number of options increases ( $1 / \mathrm{n}$ declines). Columns 2 through 5 regress the cumulative change in the share of contributions to company stock for two to five years following the initial change in the number of options offered. Because only observations for which there were no additional changes in the number of options were used, there is a substantial

\footnotetext{
${ }^{11}$ A small set of 21 plans decreased the number of offerings.
} 
reduction in the sample size as the period lengthens. We find that by three years after the initial change, for example, the coefficient estimate climbs to .59 , and by five years, the coefficient is .87 , not statistically different from one. The coefficient of .27 in the fixed effect framework in Table 7 can be viewed as a weighted average of the coefficients in Table 8, with a higher weight on the coefficients from the one-year after change and twoyear after change regressions. ${ }^{2}$ It is also worth pointing out that, after controlling for the effect of the number of options on contribution allocation, there is no additional difference in the change in company stock purchases between firms that increased investment options compared to firms that did not change the number of options. This is reflected by the insignificance of the "Did number of options stay the same?" dummy variable.

These findings could be consistent with two explanations. First, some participants may simply adjust slowly to the new investment options: Only a fraction of employees may adjust their contribution allocations each year, with some employees taking up to 4-5 years after new options are added to reduce company stock purchases. However, there is an alternative explanation that could possibly explain the results in table 8. Under the alternative, individual participants never change the fraction of contributions they allocate to company stock in response to new options, and the estimated coefficients just reflect that as existing participants leave the firm, they are replaced by new participants who follow the $1 / \mathrm{n}$ heuristic. For the table 8 results to reflect the employee turnover hypothesis, firms on average would have to replace about

\footnotetext{
${ }^{12}$ Recall the average firm is in the sample 3.4 years, so if the firm changes the number of investment options during those 3 years it will have one or two observations before the change and two or one observations after the change.
} 
20 percent of their workforce each year, and entirely replace their workforce in 5 years, an assumption about employee turnover that would seem to be too rapid. For example, using the Current Population Survey from 1994-2000, Fallick and Fleischman (2001) estimate that 7 percent of private employees leave their job in a given year, with 5 percent of full-time workers turning over. Thus, these results appear to be more consistent with a sluggish adjustment by individual employees to changes in the number of options offered than to employee turnover.

Recall that we observe only the investment decisions of the "average" worker, and have no information on the distribution of investments across workers within the firm. Our results suggest that adding more investment options to the plan reduces the purchase of company stock on average, not that every worker follows the naïve diversification heuristic. Thus, because the response to more options could differ across workers, and we do not have information on asset purchases outside the 401(k), the welfare implications of adding more options to 401(k) plans are difficult to assess.

These findings are also consistent with studies that document that participant behavior is strongly guided by inertia. Samuelson and Zeckhauser (1988) document that participants are slow to alter existing investments in their retirement plans. Madrian and Shea (2000) find that the savings behavior of participants in a 401(k) plan at a large company changed substantially when the plan switched to automatic enrollment. In particular, a substantial fraction of 401(k) participants under automatic enrollment stuck with the default contribution rate and the default fund allocation. Choi, Laibson, Madrian, and Metrick (2001) confirms these results when they expand the study to include two other firms, and are able to track participant decisions for a longer period of 
time following automatic enrollment.

\section{Effect of Employer Match in Company Stock}

Another key plan feature that could affect the share of participant contributions to company stock is whether any of the employer match is required to be in company stock. Diversification theory would predict that a participant's discretionary contributions to company stock would decrease to offset a company's match in stock, i.e., the employee would act to "undo" the employer's actions. Contrary to this prediction, Benartzi (2001) finds that contributions are significantly higher when some of the employer contribution is required to be in company stock. He finds that the mean allocation of employee contributions to company stock is 29 percent when some of the employer match is required to be in company stock, 11 percentage points higher than when the plan allows the employee free choice to invest the employer match. Supplementing his data with survey evidence, Benartzi argues that such behavior suggests that employees interpret company stock matches as an endorsement, i.e., implicit investment advice offered by the company. In one survey, Benartzi finds that 45 percent of participants would increase their own allocation to the international stock fund if the employer were to introduce a match that was all invested in an international stock fund. In another survey, Benartzi finds that only 3 percent of participants that currently do not receive an employer match would decrease their own allocation to equities if a match was offered and it was all invested in a diversified stock fund. Madrian and Shea (2000) also attribute participant behavior to stay in the default investment vehicle as accepting investment advice on the part of the company.

In our sample, 94 percent, or 3,201 firm-year observations included an employer 
match. As shown in table 9, during 1991 to 2000, 48 percent of the firms required some part of the match to be in company stock. Among plans with an employer match, the average fraction of participant contributions in company stock is 15 percent if there is no requirement that some be in company stock, while the average fraction of participant contributions in company stock is 23 percent if there is some requirement.

We estimate a regression of the fraction of participant contributions to company stock on the requirement that some part of the employer match be invested in company stock for each year and for the pooled sample to determine how this requirement affects participant choice. The significant and positive coefficients indicate that employee discretionary contributions in company stock are significantly higher when some of the employer match is also in company stock. For the pooled sample, the estimates imply that discretionary contributions are about nine percentage points higher, a substantial effect given the sample average of 19 percent. These results are contrary to diversification, which would predict a negative coefficient as employees offset the employer match in company stock, but are consistent with the endorsement effect proposed by Benartzi.

Again, an objection to the endorsement interpretation is that employees who have a preference for company stock may work for firms that offer company stock, and the relationship we document merely reflects the underlying preference for company stock. Other studies have documented the effects of an underlying strong preference for company stock or equities, showing that those who hold a high proportion of equities in pension savings also hold a high fraction of non-pension assets in equities (Bodie and Crane (1997) and Weisbenner (1999)). 
To address this issue, we first use a fixed-effects approach, which focuses on changes in employer match policy within a firm and thus controls for worker risk preferences. As shown in the last row of table 9, the estimated coefficient on whether some of the employer match is required to be in company stock is still positive and marginally significant, although reduced in magnitude substantially. The key point from the fixed-effect regression is that employees within a specific firm will not decrease, but will boost slightly (by 1.6 percentage points), their own allocation to company stock following a change in match policy to company stock.

In a second test of changes in match policy on investment decisions, we look only at firms that adjusted their match policy. We find that adjustments have not been very frequent: there are only 31 cases in which the employer match went from total choice (all cash) to some requirement for company stock, and only 33 cases in which the employer switched from some requirement on company stock to total choice. In table 10, we regress the cumulative changes for one year up to five years in discretionary contributions in company stock on the initial change in the employer match, allowing for different coefficients depending on whether the employer match was changed from total choice to company stock requirement, or from company stock requirement to total choice. Similar to the results in the fixed-effects regression, we find no evidence that employees adjust their discretionary purchases of company stock to offset either the increased or decreased company stock exposure caused by a change in match policy, even over a period as long as five years after the change. If anything, there is a gradual shift of employee contributions to company stock following a switch to a company stock match, and a gradual movement away from company stock following a switch to total 
choice (all the coefficient estimates are very imprecise given the small sample of firms changing match policy).

These results are more consistent with the endorsement hypothesis than diversification. First, if participants were guided by diversification they would offset an increased company stock match by reducing their own contributions. However, if they view the switch to company stock as an endorsement by the company, they might not make the offsetting changes. Thus, our result of zero or a slightly positive effect is consistent with the endorsement hypothesis. Conversely, participants guided by diversification would boost the share of own purchases of company stock to offset the decrease in the company match in order to obtain the pre-change level of company stock purchases. But since we observe zero or a slightly negative effect, it appears that participants must have reduced their desired total allocation to company stock after the change, again consistent with the endorsement hypothesis.

Overall, we find no evidence that workers attempt to "undo" the presence of an employer match in company stock. Indeed, we find cross-sectional evidence to the contrary; workers in firms with a match all in company stock tend to put more of their own contributions in company stock as well. This is consistent with the endorsement hypothesis. We further find that employees do not change the share of own contributions put in company stock to offset a change in the match policy of the firm. Our fixed-effects analysis appears to support the hypothesis that an employer match in company stock is interpreted as an endorsement by the company, that is, implicit investment advice to purchase company stock, although inertia could also explain the result. In either case, employees do little to offset a changed employer match policy. This result means that a 
switch to a match in company stock will result in a large share of 401(k) assets held in company stock.

\section{Effects of other plan features}

We now expand the analysis to consider the importance of other plan features, as well as firm performance and other firm-specific characteristics on discretionary company stock purchases. The results of this analysis for the pooled sample 1991-2000 are in table 11. Other plan characteristics, displayed in the upper panel of table 11, are the focus of this section. The effect of past firm performance and other firm characteristics are discussed in sections $\mathrm{E}$ and $\mathrm{F}$ below.

Not surprisingly, workers invest less in company stock if it is the first year that it is being offered in the plan. This inertia effect is sizeable, as the coefficient estimate suggests that the share of own contributions allocated to company stock is nine percentage points less if it is the first year company stock is an option in the plan (recall the unconditional average share is 19 percent).

As mentioned earlier, a small subset of the plans restrict or encourage investment in company stock. In particular, the plan may have upper or lower bounds on the amount participants can put in company stock or provide a financial incentive, such as a discount or larger match for company stock allocations. It is important to note that companies are loath to provide any investment guidance to plan participants, most likely because if firms provide investment guidance to employees, they could be held liable for any poor investment results (Section 404 (c) of ERISA). Since investment advice is not offered, plan participants may draw cues from plan features that either encourage or discourage investment in company stock. Just as the endorsement hypothesis predicts that workers 
may view a match in company stock as a signal from the company that its shares are a good investment, the endorsement hypothesis would also predict that the presence of any restrictions on company stock purchases would be viewed as a signal that company shares are not be a great investment.

As shown in table 11, we find a significant and negative coefficient on the dummy variable designating the presence of a limit on investment in company stock. The estimated coefficients for the pooled sample (first two columns), suggest that for the 4 percent of the sample with an explicit limit on the share of employee contributions in company stock, simply the presence of the limit leads to a reduction in the share by 7 percentage points, from a sample average of 19 percent. However, the amount of the limit itself does not appear to be important, since the coefficient on the amount of the limit is insignificant and close to zero. If the limit was binding for all employees, the coefficient on the limit should be one, as an increase from a limit of 10 percent to 25 percent would increase contributions to company stock by 15 percentage points.

Conversely, a handful of firms had a requirement that some portion of employee contributions must be in company stock, with a typical requirement being 50 percent (with a range of 25 to 75 percent). ${ }^{13}$ The coefficient on the variable designating this floor on the share of contributions is positive and significant, and suggests that the mere presence of a floor increases employee contributions to company stock by about 17-19 percentage points, even after controlling for the actual amount of the minimum required contribution to stock. As expected, we also find a greater share of company stock purchased at the one percent of observations that provide some type of financial incentive

\footnotetext{
${ }^{13}$ Most of the plans with this floor are employee stock ownership plans (ESOPs) that allow participant choice, subject to the minimum required investment in company stock.
} 
to buy company stock.

These findings for variables representing a ceiling or a floor provide additional evidence consistent with endorsement theory: The mere presence of a floor for company stock purchases appears to be interpreted as implicit endorsement of the firm's company stock as a good investment advice, and appears to be followed by employees, and the mere presence of a ceiling provides an endorsement or reminder to diversify one's portfolio, a warning that appears to be heeded.

Consistent with the earlier bivariate results, whether the plan requires that the match be in company stock is a significant predictor of the share of contributions in company stock in the full specification as well. At the other extreme, a small number of plans, about 2 percent, require a portion of the employer match to not be in company stock. We find in the cross section that employees of firms that have such a restriction invest about three percentage points less of employee contributions in company stock, although the results are not statistically significant $(\mathrm{p}$-value $=.19)$. The effect of introducing a restriction on workers ability to allocate match contributions to company stock is more evident in the fixed-effect framework (third column of table 11). If a firm changes match policy so that part of the match is required to be kept out of company stock, the allocation of employee contributions to company stock falls a predicted 7.5 percentage points ( $\mathrm{p}$-value $=.01$ ). Thus, employees appear to take cues from any introduction of a restriction on company stock investments in the match, and voluntarily reduce their own, discretionary allocations to company stock as well.

Most of the results outlined above in the pooled cross-section hold qualitatively in the fixed-effects framework (third column of table 11) as well. The introduction of more 
plan options reduces purchases of company stock, while adding incentives to purchase company stock increases purchases. If match policy is changed so that part of the match is required to be kept out of (kept in) company stock, the allocation of employee contributions to company stock is predicted to fall (rise slightly). Since no firm in the sample introduced, dropped, or changed the amount of the floor/minimum for the allocation of employee contributions to company stock, the amount and indicator variables for the floor were dropped from the fixed-effect regression (as was the presence of a ceiling/maximum for the allocation of employee contributions to company stock).

Overall, these results provide additional evidence consistent with endorsement effects regarding match policy. The presence of a floor or ceiling on company stock purchases affects purchases significantly, even after controlling for the amount of the limit.

\section{E. Additional effect of firm financial characteristics}

Benartzi (2001) and Sengmuller (2001) have documented that the share of employee contributions in company stock is higher when previous stock price returns have been larger. Benartzi (2001) argues that such behavior is consistent with a representativeness heuristic (Tversky and Kahneman (1974) and Griffin and Tversky (1992)), whereby investors overweight recent past returns in formulating predictions for future returns, even when future returns are largely unpredictable. In other words, workers may view recent past performance as representative of future performance of their company's stock. Consistent with this notion, numerous studies find that net inflows to mutual funds are positively related to past performance (e.g, Patel, Zeckhauser, and Hendricks (1991), Ippolito (1992), Chevalier and Ellison (1997), and Sirri and 
Tufano (1998)). Evidence from surveys of stock investors, replicated in Figures 2-5, demonstrate that realized returns in the past twelve months are an important and significant predictor of returns expected in the next twelve months, suggesting that investors may project forward past growth rates. .4

The bottom two panels of table 11 present the regression coefficients for past stock returns and the other firm characteristics. Like other studies, we generally find a positive and significant coefficient on past stock returns. For the pooled cross-section and the fixed-effect regressions, the coefficient estimates suggest only a 1.9 to 2.0 percentage point increase in the share of employee contributions allocated to company stock following a doubling in stock price over the past year. This estimate is about onethird the size of the effect Benartzi found for returns over the past year using a crosssection of firms in 1993. The relationship between returns and subsequent company stock purchases appears to have waned somewhat over time. ${ }^{1.5}$ Thus, past stock performance is significant, but the overall effect on the share of contributions to company stock is not that large.

The coefficients on other financial variables are in general similar to those found in previous studies. Employee purchases of company stock, as a share of total

\footnotetext{
${ }^{14}$ See the UBS PaineWebber Index of Investor Optimism, a monthly survey conducted by The Gallup Organization.

${ }^{15}$ Benartzi's results implied a 6.0 percentage point increase in company stock allocations following a doubling in stock price over the past year. This estimate was based on a cross-section of 140 firms in 1993 that were members of the S\&P 500. When we focus just on the 1993 cross-sectional regression, the coefficient suggests a 4.3 percentage point increase in the share of company stock purchases following a doubling in price over the past year (more than double the effect estimated over our full sample). If we further restrict the 1993 cross-section to the members of the S\&P 500, the estimate rises to 5.2 percentage points.
} 
contributions, is higher at larger firms, at firms with higher market-to-book ratios, and at firms with lower stock price volatility. Most importantly, the addition of these variables does not alter the significance or estimated magnitude of the effects of the plan characteristics, such as the number of investment options, which are the focus of the study. The coefficient on $1 / \mathrm{n}$, which was .87 in the bivariate specification of Table 7 , is essentially unchanged in the full specification that includes other plan and firm characteristics. Once the number of investment options is included in the regression, there is no time trend in the share of contributions going to company stock. The year dummies are both individually and jointly insignificant.

\section{F. More on firm performance and purchases of company stock}

We examine further the effect of past performance by including returns for two holding periods, in particular for one year and five years. Benartzi (2001) found that company stock purchases were more sensitive to long-term performance than to shortterm performance. The average past one-year return is 24 percent (median 19) and the average cumulative five-year return is 154 percent (median 92). There is also substantial variation in past performance because, in contrast to previous work on S\&P 500 firms, our sample contains some poor performers. Three-tenths of the firms had negative oneyear returns, and one-sixth had negative five-year returns.

Table 12 presents regression results focusing on the relationship between company stock purchases and past stock price performance measured over both one year and five years. Because these purchases are retirement savings, employees may not react to short-term stock price movements, but may be more apt to adjust contributions in response to long-term firm performance. Also, if investors are subject to inertia, 
adjustments may not be immediate and extend beyond one year. We also split returns by whether previous returns were positive or negative because participants may view gains and losses differently, such as the tendency for investors to hold on to losers and sell winners (Odean, 1998 and Odean, 1999). We also examine past performance relative to the S\&P 500 index in the third column.

Our results show that the largest and most significant coefficient is on negative returns in the previous five years, suggesting that participants tend to shy away from long-term losers. In addition, participants appear to respond to firm performance asymmetrically. That is, we find no change in the share of contributions going to company stock following price run ups, but we find that employees pull back contributions to company stock following long-term price declines. In particular, coefficients from the full specification presented in column 2 of table 12 indicate that a 90 percent price decline over the past five years is associated with a decline in the share of contributions allocated to company stock of 8 percentage points.

These results are counter to Sengmuller (2001) who finds a larger coefficient on positive past returns than negative past returns. The difference likely owes to our larger sample. Our sample suffers from no selection bias, and thus, on average, firms in our sample likely had worse performance than firms in his sample, which were required to be members of the S\&P 500 .

\section{What Determines Plan Design?}

Our results emphasize the importance of the features of the 401(k) savings plan in

\footnotetext{
${ }^{16}$ We also estimated quadratics of the past gains/losses to allow the coefficient on past performance to increase with larger returns, but the quadratic terms were insignificant and small in magnitude.
} 
determining the share of employee contributions allocated to company stock. Because the features go far in explaining average levels and the cross-sectional variation in levels of company stock purchases, it is important to understand how companies determine their plan features. To some extent, we also want to evaluate whether plan features might themselves reflect past firm performance, which would cloud the causality of the relationship between contribution decisions and plan features.

\section{A. Determinants of number of investment options offered}

First, we examine whether firm financial performance can explain any of the variation in the number of investment options offered. As shown in table 13, we regress the inverse of the number of investment options offered on firm characteristics and past stock returns. Estimated coefficients indicate only one consistently significant variable: firms offered more options in later years. In particular, the estimated coefficient for 2000 in the cross-section specification is -.17. Relative to 1991 , the omitted year, the coefficient implies that the number of options increases from roughly 3 (approximately the inverse of .30) to 8 (approximately the inverse of .30-.17=.13). No doubt that the increase in the number of option alternatives over time was associated with the proliferation of different types of mutual funds offered over the past decade. For example, the ICI reports that the total number of mutual funds rose from 3,405 in 1991 to 8,171 in 2000. In addition, fund types defined by investment objective (with at least 50 funds) rose from 19 categories in 1990 to 33 categories in 2000.17 Firm stock returns, market-to-book, cash flow, and the standard deviation of stock returns appear to have no effect on the number of investment options offered. Firm size, measured by the log of the

\footnotetext{
${ }^{17} 2001$ Mutual Fund Handbook, $41^{\text {st }}$ edition, Investment Company Institute, Washington, DC.
} 
book value of assets, is significant in the pooled cross-section, but the estimated effect is very small.

\section{B. Determinants of employer match required to all be in company stock}

\section{Effects of cash constraints, share ownership, and dividends}

Determinants of whether the employer match is required to all be in company stock could be guided by two models. First, a firm that is cash-constrained may require that the employer match be in company stock because the firm would be unable to match in cash (i.e., allow investment choice). This model would predict that firms with less cash flow will be more likely to offer a match in company stock. In this case, the company match serves as a source of internal financing, as cash-constrained firms issue shares in lieu of cash for the employees' retirement fund.

Alternatively, companies that have a large value in growth opportunities and intangible assets may find it beneficial to increase share ownership of its employees, due to the asymmetric information between insiders (employees) and outside shareholders (Holmstrom and Milgrom (1987)). This model would predict that firms whose value is comprised of intangible assets and growth opportunities, and hence more uncertainty about true value, will be more likely to offer a match in company stock in order to increase insider ownership. However, while increasing stock-based wealth of top executives may be important to outside shareholders, the benefits of doing this for lower level employees, whose effort will have less effect on stock price, is less clear.

We estimate a regression for whether the firm requires the employer match to all be in company stock (right panel of table 13). ${ }^{8}$ We find that indicators of firms that

\footnotetext{
${ }^{18}$ We estimate a linear regression to provide an easy-to-interpret estimate of the marginal effects of firm
} 
might benefit from higher share ownership by employees are not important - estimated coefficients on market-to-book and the standard deviation of stock returns, proxies for firms with potential asymmetric information problems, are insignificant. The results also suggest that firms do not require the employer match to be in company stock because of low cash flow. In the cross-sectional regressions, results show, if anything, a positive relationship between cash flow and employer match requirements in company stock. In the fixed effects regression, the coefficient on cash flow is negative, but it is insignificant. In addition, past stock price performance is not an important indicator of match policy. While returns over the past five years are significant, a quadrupling of stock price over the past five years would reduce the probability that the firm matches with only company stock by only 2.7 percentage points $(-.009 * 3.0)$, a small amount relative to the average of 39 percent.

Thus, we find no evidence that firms offer a match in company stock to combat informational asymmetries between insiders and outsiders, or to alleviate their financial liquidity constraints. An alternative hypothesis is that companies offer the employer match in company stock because there is a tax benefit from doing so. Firms that pay dividends may have an incentive to match in company stock because, while dividends paid on stock are not usually tax deductible, if firms contribute their employer match to a leveraged employee stock ownership plan (ESOP), meaning the matching contributions are all in company stock, dividends paid on that stock may be tax-deductible (Beatty, 1995, and Schultz and Francis, 2002). When an employer makes a contribution of stock for an employee, the value of the stock contributed by the employer is tax-deductible in 
the year of the contribution, just as would a contribution in cash. However, all future dividends paid on that stock are tax deductible as well, in effect a "double" deduction. Because the value of the stock is the discounted stream of dividends, the dividends are used as a tax deduction twice - originally when the value of the stock is deducted and then again when the dividend is actually paid.

We find, shown in table 14, that companies that require all of the company match be in company stock were significantly more likely to pay dividends and had a higher dividend yield in every year of the sample (shown for 1993-1998), and for the pooled sample. When we add either a dummy variable for whether the firm pays dividends or add the dividend yield to the regression to help explain whether companies require the match to all be in company stock (table 15), we find a positive and significant coefficient on the dividend variable. 19 If the firm pays dividends, the increase in likelihood that the employer match will be required to be all company stock is 10 percentage points (the sample average is 39 percent). A one percentage point increase in the dividend yield is associated with a 3 to 4 percentage point increase in the probability that a firm's match is all company stock.

Thus, whether the firm pays dividends is a significant determinant of the employer match in company stock. This link to dividends likely reflects that when the match is in company stock, then the match contributions can be paid into a leveraged ESOP. This is desirable, because then the subsequent dividends paid on the stock will be considered compensation expense and thus will reduce a firm's future taxes.

\footnotetext{
${ }^{19}$ We also estimated the regression including the return variables. Their inclusion reduces the sample size by a quarter to 2294 observations. The coefficient on the pay dividends dummy is .094 (standard error .049 ) and the variable on the dividend yield is 2.80 (standard error of 1.20).
} 
While firms may enjoy the tax benefit, this match policy is potentially costly to employees. Because employees do not appear to offset company stock matches, the match in company stock could lead to a significant concentration of 401(k) assets in company stock, and thus a very risky retirement portfolio for employees. However, to the extent that the company match is larger when it is all given in company stock, a higher employer contribution may offset some of the costs of having a significant concentration of retirement plan assets in company stock. Perhaps employers pass the tax benefit to employees via more generous matching contributions.

To assess whether firms that match only with company stock make larger contributions, we compare the ratio of the amount of the match to the amount of participant contributions for firms that require all of the match in company stock with firms that do not (table 16). Our results indicate that when the match is all in company stock, the mean match-to-participant contribution ratio is 46 percent (median 37 percent), nearly identical as that for plans without the requirement, which have an average matchto-participant ratio of 48 percent (median 36 percent). These results are confirmed when we examine the size of the match the year before and the year after a change in match policy (right panel of table 18). Thus, we do not find that the match is larger for companies that match in company stock.

\section{Effects of market timing}

Market-timing behavior has been observed for grants of employee stock options to top executives, as stock prices tend to rise following new grants (Yermack, 1997). A natural question to ask is what is the stock price performance following a change in match policy. 
To test market timing in the context of match policy, we examine stock price returns for one year and two years following changes in the company match policy from total choice to all in company stock and from all in company stock to total choice. There are 19 firms in the sample that switch their match policy from offering a match all required to be in company stock to offering a match with employee investment choice for all of the match (or vice versa), note the exact date of the switch in the 11-k filing, and have returns on CRSP for at least two years before and two years after the switch. 20 While our sample size is small, because not many firms have changed their company match policy, we find no evidence that firms timed the change of their match policy to benefit their employees (tables 17a and 17b).

Returns for companies that switch from choice to all stock show substantially poor performance after the switch. The company stock underperforms the market (table 17b), as well as the stock's own historical performance (table 17a) following the switch of match policy to all stock. On the other hand, companies that switch match policy from all stock to allowing choice subsequently enjoy large positive returns, both relative to the market and to their own past performance. Again, caution should be exercised when viewing these findings due to the small sample size. At a minimum, however, both of these results run counter to the hypothesis that a firm may switch the match to all company stock prior to the public revelation of good news (and the subsequent run up in price) and allow employees to scale back their company stock purchases by eliminating a

\footnotetext{
${ }^{20}$ We identified 32 firms that switched match policy from offering a match all required to be in company stock to offering a match with total employee investment choice (or vice versa). Five of these firms were dropped because we could not identify the precise date of the switch in policy. An additional eight firms were dropped due to an absence of return data for two years before and after the switch.
} 
match all in company stock ahead of bad news (and the subsequent fall in price).

\section{Summary}

We have examined the purchase of company stock in $401(\mathrm{k})$ plans using panel data from 1991-2000 for 994 companies. This research examines features of the 401(k) plan in addition to firm performance as factors determining the decision to purchase company stock, and includes many more companies than previously studied. Our main conclusion is that the characteristics of the 401(k) plan strongly influence investment decisions by participants because they follow naïve diversification rules and view plan features as implicit investment advice by the firm. Thus, differences in plan design can help explain differences in the concentration of company stock in retirement plans across firms.

Our principal findings are these: First, the number of investment alternatives offered by the plan is a very significant indicator of the share of contributions to company stock. We find evidence consistent with investors following naive diversification rules, and that the share of participant contributions allocated to company stock is substantially lower in plans that offer more alternatives. We cannot reject the simple " $1 / \mathrm{n}$ " diversification rule for company stock in our cross-sectional analysis, indicating that workers appear to put $1 / \mathrm{n}$ of their contributions in company stock, where " $\mathrm{n}$ " is the total number of investment options. Following an increase in fund options within a firm, employees appear to continue to adopt the " $1 / \mathrm{n}$ " strategy. However, the full reduction in the share of contributions allocated to company stock in response to an increase in investment options takes about 4 to 5 years, likely due to inertia in investor behavior. 
Second, employees do not offset the employer's match. Employees put a larger share of their own contributions in company stock when the match is required to be in company stock. In addition, a switch from allowing the employee to invest the match without restriction to requiring that the match be all in company stock is not offset by the employee investing less of his own contributions in company stock.

Third, we present evidence that is consistent with endorsement effects. Employees appear to interpret restrictions on asset allocation provided by the firm as providing implicit investment advice regarding the purchase of company stock. In the cross-section, the employees of firms that have a match in company stock put more of their own contributions in company stock. The employees of firms that limit the share of own contributions that can be put in company stock or require that part of the match not be in company stock invest less of their own contributions in company stock - even after controlling for the amount of the limit. These findings are consistent with Benartzi (2001) and Madrian and Shea (2000) that found evidence that participants appear to interpret the match and the default contribution allocation as implicit investment advice.

Because the plan features are so important in determining the purchase and holdings of company stock, we examine what determines the number of investment options offered and the employer match policy. In terms of number of investment options offered, our results suggest that firms have offered more options in recent years, possibly because the proliferation of mutual funds has made it easier to offer many alternatives. In terms of the employer match, we find no evidence that firms offer an employer match all in company stock because they are cash constrained, and thus have no other means of making a match. Rather, the only significant determinant of the 
employer match in company stock is whether the firm pays dividends. This link to dividends likely reflects that when the match is in company stock, then the match contributions can be paid into a leveraged ESOP. This is desirable, because then the subsequent dividends paid on the stock will be considered compensation expense and thus will reduce a firm's future taxes. We also test if firms switch to an employer match in company stock ahead of good news, perhaps to benefit employees, but we find no supporting evidence.

These results have several implications for public policy. In response to Enron's collapse, there has been much concern expressed about the concentration of 401(k) assets held in company stock. Given the naïve diversification strategies employees appear to use, absent an explicit cap on company stock purchases or holdings, policy makers could improve diversification by requiring firms that offer company stock to also offer a minimum number of alternative investment funds. President Bush has recently proposed that firms urge workers to diversify their retirement portfolio by including reminders in the quarterly plan reports. Our results concerning the importance of endorsement effects on purchases of company stock suggest that such a quarterly reminder could have an effect on asset holdings. In addition, President Bush has proposed a partial privatization of Social Security in which two percent of salary would be placed in a worker's account to be invested by the worker. The evidence in this paper and others that workers appear to adopt naïve diversification strategies suggests that the number and type of investment options the government chooses to offer will have an important effect on the ultimate composition of the assets in workers' accounts. 


\section{References}

Beatty, Anne, 1995, The cash flow and informational effects of employee stock ownership plans, Journal of Financial Economics 38, 211-240.

Benartzi, Shlomo, 2001, Excessive extrapolation and the allocation of 401(k) accounts to company stock, Journal of Finance 56, 1747-64.

Benartzi, Shlomo, and Richard H. Thaler, 2001, Naïve diversification strategies in retirement savings plans, American Economic Review 91-1, 79-98.

Bodie, Zvi, and Dwight B. Crane, 1997, Personal investing: Advice, theory, and evidence, Financial Analysts Journal, 13-23.

Chevalier, Judith, and Glenn Ellison, 1997, Risk taking by mutual funds as a response to incentives, Journal of Political Economy 105-6, 1167-1200.

Choi, James, Laibson, David, Madrian Brigitte, and Metrick, Andrew, 2001, For better or for worse: Default effects and 401(K) savings behavior. NBER Working paper 8651, December.

Coval, Joshua D., and Tobias J. Moskowitz, 1999, Home bias at home: Local equity preference in domestic portfolios, Journal of Finance 54, 1-39.

Fallick, Bruce C., and Charles A. Fleischman, 2001, Employer-to-employer flows in the U.S. labor market, Working Paper, Federal Reserve Board.

French, Ken R., and James M. Poterba, 1991, Investor diversification and international equity markets, American Economic Review 81, 222-226.

Goetzmann, William and Kumar, Alok, 2001, Equity portfolio diversification, NBER Working Paper 8686, December.

Griffin, Dale, and Amos Tversky, 1992, The weighing of evidence and the determinants of confidence, Cognitive Psychology 24, 411-435.

Heath, Chip, and Amos Tversky, 1991, Preferences and beliefs: Ambiguity and competence in choice under uncertainty, Journal of Risk and Uncertainty 4, 5-28.

Holden, Sarah and VanDerhei, Jack, 2001, 401(k) plan asset allocation, account balances, and loan activity in 2000, Investment Company Institute Perspective 7(5).

Holmstrom, Bengt and Paul Milgrom, 1987, Aggregation and linearity in the provision of intertemporal incentives, Econometrica 55, 303-328. 
Huberman, Gur, 2001, Familiarity breeds investment, Review of Financial Studies 14(3), 659-680.

Ippolito, Richard A., 1992, Consumer reaction to measures of poor quality: Evidence from the mutual fund industry, Journal of Law and Economics 35, 45-75.

John Hancock Financial Services, 2001, The seventh defined contribution plan survey.

Langer, Ellen J., 1975, The illusion of control, Journal of Personality and Social Psychology 32-2, 311-328.

Lintner, John, 1965, The valuation of risk assets and the selection of risky investments in stock portfolios and capital budgets, Review of Economics and Statistics 47, 13-37.

Madrian, Brigitte, and Shea, Dennis 2000, The power of suggestion: Inertia in 401(k) participation and savings behavior, NBER Working Paper No. 7682, May.

Markowitz, Harry M., 1952, Portfolio selection, Journal of Finance 7, 77-91.

Meulbroek, Lisa, 2002, Company stock in pension plans: How costly is it?, Working paper, Harvard University.

Odean, Terrance, 1998, Are investors reluctant to realize their losses? Journal of Finance $53,1775-1798$.

Odean, Terrance, 1999, Do investors trade too much? American Economic Review 89, 1279-1298.

Patel, Jayendu, Richard Zeckhauser, and Darryll Hendricks, 1991, The rationality struggle: Illustrations from financial markets, American Economic Review 81-2, 232-236.

Profit Sharing/401(k) Council of America, $44^{\text {th }}$ Annual survey of profit sharing and 401(k) plans.

Samuelson, William, and Richard J. Zeckhauser, 1988, Status quo bias in decision making, Journal of Risk and Uncertainty 1, 7-59.

Schultz, Ellen E., and Theo Francis, 2002, Hot tax break: 401(k)s - Why firms stuff plans with stock, Wall Street Journal, January.

Sengmuller, Paul, 2001, Performance predicts asset allocation: Company stock in 401(k) plans, Working paper, Columbia University, November.

Sharpe, William F., 1964, Capital asset prices: A theory of market equilibrium under conditions of risk, Journal of Finance 19, 425-442. 
Sirri, Erik and Peter Tufano, 1998, Costly search and mutual fund flows, Journal of Finance, Vol. 53, no. 5, October, 1589-1621.

Topline, 2002, UBS index of investor optimism, March.

Tversky, Amos and Daniel Kahneman, 1974, Judgement under undertainty: Heuristics and biases, Science 185, 1124-1131.

Vanguard, 2002, Vanguard Participant Monitor: Expecting lower market returns in the near term, January.

Weisbenner, Scott, 1999, Do pension plans with participant choice teach households to hold more equity?, FEDS Working Paper 1999-61, November.

Yermack, David, 1997, Good timing: CEO stock option awards and company news announcements, Journal of Finance 52, 449-476. 


\begin{tabular}{|c|c||c|c|c|}
\hline \multicolumn{7}{|c|}{ Table 1: Sample Composition } \\
\cline { 1 - 2 } Year & $\begin{array}{c}\text { Number of } \\
\text { observations }\end{array}$ & $\begin{array}{c}\text { Number of } \\
\text { years in sample }\end{array}$ & $\begin{array}{c}\text { Number } \\
\text { of firms }\end{array}$ & $\begin{array}{c}\text { Number of } \\
\text { observations }\end{array}$ \\
\hline 1991 & 51 & 1 & 186 & 186 \\
\hline 1992 & 190 & 2 & 224 & 448 \\
\hline 1993 & 319 & 3 & 186 & 558 \\
\hline 1994 & 371 & 4 & 115 & 460 \\
\hline 1995 & 465 & 5 & 94 & 470 \\
\hline 1996 & 572 & 6 & 79 & 474 \\
\hline 1997 & 637 & 7 & 72 & 504 \\
\hline 1998 & 667 & 8 & 32 & 256 \\
\hline 1999 & 96 & 9 & 4 & 36 \\
\hline \hline 2000 & 44 & 10 & 2 & 20 \\
\hline \hline TOTAL & $\mathbf{3 4 1 2}$ & TOTAL & $\mathbf{9 9 4}$ & $\mathbf{3 4 1 2}$ \\
\hline
\end{tabular}

Data collected for all U.S. companies listed in Compustat any year from 1993 to 1999 that filed an 11-k at least once during 1994-2001. See text for further details. 


\begin{tabular}{|c|c|c|}
\hline \multicolumn{2}{|c|}{ Table 2: Industry Composition of Sample } \\
\hline Mining & Number of firms & Percent of sample \\
\hline Oil and Gas & 15 & $1.5 \%$ \\
\hline Construction & 29 & 2.9 \\
\hline Food & 14 & 1.4 \\
\hline Basic Materials & 28 & 2.8 \\
\hline Biotech / Medical & 56 & 5.6 \\
\hline Manufacturing & 93 & 9.4 \\
\hline Transportation & 92 & 9.3 \\
\hline Telecom & 29 & 2.9 \\
\hline Utilities & 37 & 3.7 \\
\hline Retail / Wholesale Trade & 73 & 7.3 \\
\hline Financial & 111 & 11.2 \\
\hline Technology & 206 & 20.7 \\
\hline Services & 153 & 15.4 \\
\hline \hline TOTAL & 58 & 5.8 \\
\hline \hline Ever a Member of & $\mathbf{9 9 4}$ & $\mathbf{1 0 0}$ \\
\hline S\&P 500 (1980-1999) & 269 & 27.1 \\
\hline
\end{tabular}

Data collected for all U.S. companies listed in Compustat any year from 1993 to 1999 that filed an 11-k at least once during 1994-2001. See text for further details. 


\begin{tabular}{|c|c|c|c|}
\hline \multicolumn{4}{|c|}{ Table 3a: Composition of 1998 Sample } \\
\hline Index & $\begin{array}{c}\text { Number of } \\
\text { firms in sample }\end{array}$ & Percent of sample & $\begin{array}{c}\text { Percent of all } \\
\text { firms in sample* }\end{array}$ \\
\hline S\&P 500 & 148 & $22 \%$ & $30 \%$ \\
\hline S\&P MidCap 400 & 86 & 13 & 22 \\
\hline S\&P SmallCap 600 & 107 & 16 & 18 \\
\hline Not S\&P 1500 & 326 & 49 & 5 \\
\hline \hline Total & $\mathbf{6 6 7}$ & $\mathbf{1 0 0 \%}$ & $\mathbf{9 \%}$ of all firms \\
\hline
\end{tabular}

* There were 7,501 U.S. firms with non-missing market value and total assets listed on COMPUSTAT.

\begin{tabular}{|c|c|c|c|}
\hline \multicolumn{5}{|c|}{$\begin{array}{c}\text { Table 3b: Characteristics of 1998 Sample Compared to } \\
\text { S\&P 1500 and Universe of Public Firms }\end{array}$} \\
\hline & Sample & S\&P 1500 & All Public Firms* \\
\hline S\&P 1500 & $51 \%$ & $100 \%$ & $20 \%$ \\
\hline Technology & $16 \%$ & $19 \%$ & $24 \%$ \\
\hline $\begin{array}{c}\text { Book Assets } \\
\text { (\$ millions) }\end{array}$ & 7,207 & 9,773 & 2,335 \\
\hline $\begin{array}{c}\text { \# Employees } \\
\text { (000s) }\end{array}$ & $121-1,004-12,048$ & $248-1,487-18,002$ & $7-137-2,486$ \\
\hline $\begin{array}{c}\text { Market/Book } \\
\text { ratio }\end{array}$ & 13.0 & 19.9 & 5.4 \\
\hline $\begin{array}{c}\% \text { of firms that } \\
\text { repurchase stock }\end{array}$ & $1.0-1.3-3.0$ & $.9-6.6-45$ & $.02-.5-10.2$ \\
\hline $\begin{array}{c}\text { Repurchase yield } \\
\text { (percent) }\end{array}$ & $48 \%$ & 2.0 & $.9-1.5-3.3$ \\
\hline
\end{tabular}

Mean is reported in first row, $10^{\text {th }}$ percentile - median $-90^{\text {th }}$ percentile are in second row.

The share repurchase yield is the amount spend to repurchase shares divided by the average of the beginning- and end-of-year market value.

* There were 7,501 U.S. firms with non-missing market value and total assets listed on COMPUSTAT.

\begin{tabular}{|c|c|c|c|}
\hline \multicolumn{4}{|c|}{ Table 3c: Aggregate 401-k Plan Statistics for 1998 Sample, } \\
Public Firms, and All Firms (public and private) (\$ billions) \\
\hline & $\begin{array}{c}\text { Sample }- \\
667 \text { firms }\end{array}$ & $\begin{array}{c}\text { All Public } \\
\text { Firms }\end{array}$ & All Firms \\
\hline Total 401-k Assets & $\$ 274$ & $\$ 698$ & $\$ 1645$ \\
\hline Total 401-k Assets in Company Stock & 102 & 273 & 273 \\
\hline $\begin{array}{c}\text { Total Contributions to Plan } \\
\text { (employee and employer) during 1998* }\end{array}$ & 15.5 & 49.2 & 134.7 \\
\hline $\begin{array}{c}\text { Total Contributions to Plan allocated to } \\
\text { Company Stock during 1998 }\end{array}$ & 4.9 & NA & NA \\
\hline
\end{tabular}

Data on 401-k assets for all public firms are from 19985500 filings with the Department of Labor; data for all public and private firms are from Department of Labor. Company stock for all public firms and all firms excludes any stock indirectly held in trusts and pooled accounts.

Employer contributions constitute $29 \%$ of total contributions for the sample and $31 \%$ for all public firms. 
Table 4: Plan Characteristics

\begin{tabular}{|c|c|c|}
\hline & $\begin{array}{l}\text { Full Sample - } \\
3412 \text { obs. }\end{array}$ & $\begin{array}{c}1998- \\
667 \text { observations } \\
\end{array}$ \\
\hline \multicolumn{3}{|c|}{ EMPLOYEE CONTRIBUTIONS } \\
\hline Number of investment options & $\begin{array}{l}\text { mean }=7.5 \\
\text { IQR: } 5-9\end{array}$ & $\begin{array}{l}\text { mean }=9.6 \\
\text { IQR: } 7-11\end{array}$ \\
\hline $\begin{array}{l}\text { Is this the first year company stock is offered } \\
\text { as an option in the plan? }\end{array}$ & $6.4 \%$ & $8.2 \%$ \\
\hline $\begin{array}{l}\text { Is there a limit placed on investment in } \\
\text { company stock (i.e., is there a ceiling)? }\end{array}$ & $3.6 \%$ & $4.0 \%$ \\
\hline If so, what is the limit/ceiling? & $\begin{array}{l}\text { ranges from } 10-50 \% \\
\text { of total contributions }\end{array}$ & $\begin{array}{l}\text { ranges from } 10-50 \% \\
\text { of total contributions }\end{array}$ \\
\hline $\begin{array}{l}\text { Is part of the employee contributions required } \\
\text { to be in company stock (i.e., is there a floor)? }\end{array}$ & $.5 \%$ & $.4 \%$ \\
\hline If so, what is the minimum/floor? & $\begin{array}{l}\text { ranges from } 25-75 \% \\
\text { of total contributions }\end{array}$ & $\begin{array}{l}\text { ranges from } 25-75 \% \\
\text { of total contributions }\end{array}$ \\
\hline $\begin{array}{l}\text { Is there an incentive provided to invest } \\
\text { contributions in company stock (i.e., larger } \\
\text { match and/or discounted price)? }\end{array}$ & $1.0 \%$ & $1.0 \%$ \\
\hline
\end{tabular}

\section{EMPLOYER/MATCH CONTRIBUTIONS}

\begin{tabular}{|l|c|c|}
\hline $\begin{array}{l}\text { Does the employer make contributions } \\
\text { (offer a match)? }\end{array}$ & $94 \%$ \\
\hline $\begin{array}{l}\text { Does the employer require at least part of the } \\
\text { match to be in company stock?* }\end{array}$ & $48 \%$ & $41 \%$ \\
\hline $\begin{array}{l}\text { Does the employer require all of the match to } \\
\text { be in company stock?* }\end{array}$ & $39 \%$ & $32 \%$ \\
\hline $\begin{array}{l}\text { Does the employer require at least part of the } \\
\text { match } \text { not be in company stock?* }\end{array}$ & $1.8 \%$ & $1.1 \%$ \\
\hline $\begin{array}{l}\text { Ratio of employer contributions (match) } \\
\text { to employee contributions }\end{array}$ & $\begin{array}{c}\text { mean }=.47 \\
\text { median }=.37\end{array}$ & $\begin{array}{c}\text { mean }=.45 \\
\text { median }=.37\end{array}$ \\
\hline \multicolumn{2}{|c|}{$45 \%$} & $40 \%$ \\
\hline $\begin{array}{l}\text { Is at least part of employee or employer } \\
\text { contributions required to be in company stock? }\end{array}$ & \\
\hline
\end{tabular}

* Conditional on the employer making contributions to the plan (offering a match). 
Table 5: Distribution of Employee Contributions Invested in Company Stock and Number of Investment Alternatives Across Sample (3412 firm-year observations)

\begin{tabular}{|c|c|c|}
\hline & $\begin{array}{c}\text { Fraction of Employee Contributions } \\
\text { Invested in Company Stock (percent) }\end{array}$ & $\begin{array}{c}\text { Number of Investment } \\
\text { Alternatives Offered }\end{array}$ \\
\hline $1^{\text {st }} \%$ & .4 & 3 \\
\hline $25^{\text {th }} \%$ & 6.7 & 5 \\
\hline Median & $\mathbf{1 3 . 7}$ & $\mathbf{7}$ \\
\hline $75^{\text {th }} \%$ & 26.5 & 18 \\
\hline $99^{\text {th }} \%$ & 72.8 & $\mathbf{7 . 5}$ \\
\hline \hline Mean & $\mathbf{1 8 . 9}$ & 5.3 \\
\hline Std. Deviation & 16.6 & \\
\hline
\end{tabular}




\begin{tabular}{|c|c|c|c|c|c|c|c|c|c|}
\hline \multirow[b]{3}{*}{$\begin{array}{l}\text { Share of participant } \\
\text { contributions in } \\
\text { company stock } \\
\text { (average) }\end{array}$} & \multicolumn{9}{|c|}{ Number of Investment Options } \\
\hline & 2 & 3 & 4 & 5 & 6 & 7 & 8 & 9 & $10+$ \\
\hline & $\begin{array}{c}.59 \\
(.08)\end{array}$ & $\begin{array}{c}.36 \\
(.04)\end{array}$ & $\begin{array}{c}.26 \\
(.02)\end{array}$ & $\begin{array}{c}.22 \\
(.01)\end{array}$ & $\begin{array}{c}.18 \\
(.01)\end{array}$ & $\begin{array}{c}.18 \\
(.01)\end{array}$ & $\begin{array}{c}.17 \\
(.01)\end{array}$ & $\begin{array}{c}.14 \\
(.01)\end{array}$ & $\begin{array}{c}.13 \\
(.01)\end{array}$ \\
\hline $\begin{array}{l}\text { Share of participant } \\
\text { contributions in } \\
\text { company stock } \\
\text { (median) }\end{array}$ & $\begin{array}{c}.61 \\
(.05)\end{array}$ & $\begin{array}{c}.31 \\
(.02)\end{array}$ & $\begin{array}{c}.21 \\
(.01)\end{array}$ & $\begin{array}{c}.18 \\
(.01)\end{array}$ & $\begin{array}{c}.13 \\
(.01)\end{array}$ & $\begin{array}{c}.15 \\
(.01)\end{array}$ & $\begin{array}{c}.12 \\
(.01)\end{array}$ & $\begin{array}{c}.11 \\
(.01)\end{array}$ & $\begin{array}{c}.10 \\
(.01)\end{array}$ \\
\hline $\begin{array}{l}\text { Number of firm- } \\
\text { year observations }\end{array}$ & 17 & 128 & 406 & 483 & 561 & 456 & 423 & 274 & 664 \\
\hline
\end{tabular}

The standard error calculations allow for heteroskedasticity and correlation across observations of the same firm. 


\begin{tabular}{|c|c|c|c|c|c|}
\hline \multicolumn{6}{|c|}{$\begin{array}{l}\text { Table 7: Regression of the Share of Own Contributions in Company Stock } \\
\text { on the Number of Investment Options Offered } \\
\text { Dependent variable }= \\
\text { Employee Contributions in Company Stock/Total Employee Contributions }\end{array}$} \\
\hline Sample & $\begin{array}{l}\text { Coefficient on ( } 1 \text { / \# of options) } \\
\text { Standard error in parentheses }\end{array}$ & Constant & $\begin{array}{l}\text { Firm- } \\
\text { effect }\end{array}$ & $\mathrm{R}^{2}$ & \# obs. \\
\hline 1993 & $\begin{array}{c}.73 \\
(.18) \\
\end{array}$ & $\begin{array}{c}.07 \\
(.04) \\
\end{array}$ & No & .070 & 319 \\
\hline 1994 & $\begin{array}{c}.78 \\
(.17)\end{array}$ & $\begin{array}{c}.06 \\
(.03)\end{array}$ & No & .073 & 371 \\
\hline 1995 & $\begin{array}{l}1.04 \\
(.15) \\
\end{array}$ & $\begin{array}{c}.02 \\
(.02) \\
\end{array}$ & No & .120 & 465 \\
\hline 1996 & $\begin{array}{c}.99 \\
(.15)\end{array}$ & $\begin{array}{c}.03 \\
(.02) \\
\end{array}$ & No & .105 & 572 \\
\hline 1997 & $\begin{array}{l}1.08 \\
(.15) \\
\end{array}$ & $\begin{array}{c}.02 \\
(.02) \\
\end{array}$ & No & .117 & 637 \\
\hline 1998 & $\begin{array}{l}1.02 \\
(.16)\end{array}$ & $\begin{array}{c}.04 \\
(.02) \\
\end{array}$ & No & .093 & 667 \\
\hline $1991-2000$ & $\begin{array}{c}.87 \\
(.08) \\
\end{array}$ & $\begin{array}{c}.05 \\
(.01) \\
\end{array}$ & No & .124 & 3412 \\
\hline $1991-2000$ & $\begin{array}{c}.27 \\
(.04) \\
\end{array}$ & - & Yes & $\begin{array}{c}.044 \\
\text { within }\end{array}$ & 3412 \\
\hline
\end{tabular}

All regression estimation allows for heteroskedasticity. The standard error calculation in the pooled crosssection regression allows for correlation across observations of the same firm as well. 


\section{Table 8: Regression of Change in Share of Own Contributions in Company Stock Upon Change in the Number of Investment Options Offered (standard error in parentheses)}

\section{Dependent variable $=$}

Change in (Employee Contributions in Company Stock / Total Employee Contributions)

\begin{tabular}{|c|c|c|c|c|c|}
\hline & $\begin{array}{c}(1) \\
\Delta \mathrm{CS} / \mathrm{T} \\
(\mathrm{t}+1)-\mathrm{t}\end{array}$ & $\begin{array}{c}(2) \\
\Delta \mathrm{CS} / \mathrm{T} \\
(\mathrm{t}+2)-\mathrm{t}\end{array}$ & $\begin{array}{c}(3) \\
\Delta \mathrm{CS} / \mathrm{T} \\
(\mathrm{t}+3)-\mathrm{t}\end{array}$ & $\begin{array}{c}(4) \\
\Delta \mathrm{CS} / \mathrm{T} \\
(\mathrm{t}+4)-\mathrm{t}\end{array}$ & $\begin{array}{c}(5) \\
\Delta \mathrm{CS} / \mathrm{T} \\
(\mathrm{t}+5)-\mathrm{t}\end{array}$ \\
\hline $\begin{array}{c}\Delta \text { in }(1 / \text { \#options }) \\
(t+1)-t\end{array}$ & $\begin{array}{l}.18 \\
(.07)\end{array}$ & $\begin{array}{c}.34 \\
(.12) \\
\end{array}$ & $\begin{array}{c}.59 \\
(.09) \\
\end{array}$ & $\begin{array}{c}.71 \\
(.20) \\
\end{array}$ & $\begin{array}{c}.87 \\
(.27) \\
\end{array}$ \\
\hline $\begin{array}{l}\text { Did number of } \\
\text { options stay the } \\
\text { same? }\end{array}$ & $\begin{array}{l}-.001 \\
(.004)\end{array}$ & $\begin{array}{l}-.001 \\
(.009)\end{array}$ & $\begin{array}{l}.018 \\
(.012)\end{array}$ & $\begin{array}{l}.029 \\
(.027)\end{array}$ & $\begin{array}{l}-.053 \\
(.055)\end{array}$ \\
\hline $\mathrm{R}^{2}$ & .014 & .032 & .059 & .055 & .080 \\
\hline \# obs. & 2418 & 1148 & 476 & 185 & 65 \\
\hline
\end{tabular}

$\mathrm{CS} / \mathrm{T}=$ employee contributions in company stock / total employee contributions.

$1 /$ \#options $=1 /$ total number of investment options offered.

"Did number of options stay the same?" is a dummy variable that will test whether, after controlling for the effect of the number of options on contribution allocation, there is any additional difference in the change in company stock investment between firms that did not change the number of options relative to those firms that did.

Specifications (1) - (5) examine how the fraction of employee contributions invested in company stock changes $(\Delta \mathrm{CS} / \mathrm{T})$ in response to a change in the number of options during year $\mathrm{t}(\Delta 1 /$ funds). There are 2418 firm-year observations where data on the firm's plan is available for the next year. Of these 2418 observations, 1730 had no change in the number of investment options offered, 667 increased the number of options offered, and 21 decreased the number of funds available to employees.

To isolate the effect of a specific increase in investment options on contribution allocation decisions over time, specifications (2) - (5) focus on firms that had no subsequent change in the number of investment options after the initial change during time t. It also includes the firms that had no change in fund options, even in year t. Thus, specification (5) measures how the fraction of contributions allocated to company stock has changed over the next five years for firms that either made no change in fund options or the group of firms that increased investment options (decrease in 1/funds) during year $t$, but had no further change in the number of options after year $\mathrm{t}$. 


\begin{tabular}{|c|c|c|c|c|c|c|}
\hline \multicolumn{7}{|c|}{$\begin{array}{l}\text { Table 9: Regression of the Share of Own Contributions in Company Stock } \\
\text { Upon whether Part of Employer Contribution is Required to be in Company Stock }\end{array}$} \\
\hline \multirow[b]{2}{*}{ Sample } & \multirow[b]{2}{*}{$\begin{array}{l}\text { Fraction with } \\
\text { part of match } \\
\text { required to be } \\
\text { in company } \\
\text { stock }\end{array}$} & \multicolumn{5}{|c|}{$\begin{array}{c}\text { Dependent variable = } \\
\text { Employee Contributions in Company Stock / } \\
\text { Total Employee Contributions }\end{array}$} \\
\hline & & $\begin{array}{l}\text { Coefficient on } \\
\text { (Is part of match } \\
\text { required to be in } \\
\text { company stock?) } \\
\text { Standard error } \\
\text { in parentheses }\end{array}$ & Constant & $\begin{array}{l}\text { Firm- } \\
\text { effect? }\end{array}$ & $\mathrm{R}^{2}$ & \# obs. \\
\hline 1993 & .55 & $\begin{array}{c}.066 \\
(.021)\end{array}$ & $\begin{array}{c}.20 \\
(.01)\end{array}$ & No & .031 & 291 \\
\hline 1994 & .49 & $\begin{array}{c}.089 \\
(.018)\end{array}$ & $\begin{array}{l}.17 \\
(.01)\end{array}$ & No & .066 & 340 \\
\hline 1995 & .48 & $\begin{array}{l}.085 \\
(.016)\end{array}$ & $\begin{array}{l}.16 \\
(.01)\end{array}$ & No & .062 & 433 \\
\hline 1996 & .47 & $\begin{array}{l}.075 \\
(.014)\end{array}$ & $\begin{array}{l}.15 \\
(.01)\end{array}$ & No & .055 & 541 \\
\hline 1997 & .45 & $\begin{array}{c}.079 \\
(.013)\end{array}$ & $\begin{array}{l}.13 \\
(.01)\end{array}$ & No & .067 & 604 \\
\hline 1998 & .41 & $\begin{array}{l}.084 \\
(.012)\end{array}$ & $\begin{array}{l}.13 \\
(.01)\end{array}$ & No & .078 & 637 \\
\hline $\begin{array}{l}1991- \\
2000\end{array}$ & .48 & $\begin{array}{l}.085 \\
(.012)\end{array}$ & $\begin{array}{l}.15 \\
(.01)\end{array}$ & No & .064 & 3201 \\
\hline $\begin{array}{l}1991- \\
2000\end{array}$ & & $\begin{array}{l}.016 \\
(.008)\end{array}$ & - & Yes & $\begin{array}{c}.002 \\
\text { within }\end{array}$ & 3201 \\
\hline
\end{tabular}

Averages and regressions calculated using firm-year observations where the employer made contributions to the plan. The employer did not make contributions to the plan for 211 firm-years, leaving 3201 observations (3412-211).

All regression estimation allows for heteroskedasticity. The standard error calculation in the pooled crosssection regression allows for correlation across observations of the same firm as well. 


\section{Table 10: Regression of Change in Share of Own Contributions in Company Stock Upon Change in Employer Match Policy (standard error in parentheses)}

\section{Dependent variable $=$}

Change in (Employee Contributions in Company Stock / Total Employee Contributions)

\begin{tabular}{|c|c|c|c|c|c|}
\hline & $\begin{array}{c}(1) \\
\Delta \mathrm{CS} / \mathrm{T} \\
(\mathrm{t}+1)-\mathrm{t}\end{array}$ & $\begin{array}{c}\Delta \mathrm{CS} / \mathrm{T} \\
(\mathrm{t}+2)-\mathrm{t}\end{array}$ & $\begin{array}{c}\Delta \mathrm{CS} / \mathrm{T} \\
(\mathrm{t}+3)-\mathrm{t}\end{array}$ & $\begin{array}{c}\Delta \mathrm{CS} / \mathrm{T} \\
(\mathrm{t}+4)-\mathrm{t}\end{array}$ & $\begin{array}{c}\Delta \mathrm{CS} / \mathrm{T} \\
(\mathrm{t}+5)-\mathrm{t}\end{array}$ \\
\hline $\begin{array}{c}\text { Did employer switch from } \\
\text { no requirement to some } \\
\text { required company stock? }\end{array}$ & $\begin{array}{c}.004 \\
(.008)\end{array}$ & $\begin{array}{c}.014 \\
(.015)\end{array}$ & $\begin{array}{c}.014 \\
(.023)\end{array}$ & $\begin{array}{c}.030 \\
(.039)\end{array}$ & .026 \\
\hline $\begin{array}{c}\text { Did employer switch from } \\
\text { some required company } \\
\text { stock to no requirement? }\end{array}$ & -.010 & -.012 & -.011 & -.053 & -.0801 \\
\hline Constant & $-.008)$ & $(.019)$ & $(.029)$ & $(.055)$ & $(.118)$ \\
\hline $\mathrm{R}^{2}$ & $(.001)$ & -.008 & -.019 & -.028 & -.043 \\
\hline$\#$ obs. & .001 & $.003)$ & $(.005)$ & $(.008)$ & $(.011)$ \\
\hline
\end{tabular}

$\mathrm{CS} / \mathrm{T}$ = employee contributions allocated in company stock / total employee contributions.

"Did employer switch from no requirement to required company stock?" represents whether such a change occurred from year $\mathrm{t}$ to $\mathrm{t}+1$.

There are 2247 firm-year observations where data on the firm's plan is available for the next year, and the employer made contributions both years. Of these 2247 observations, 2183 had no change in the employer match policy from this year to next year, 31 went from having no restrictions on how employer contributions can be invested this year to requiring at least part to be in company stock next year, and the remaining 33 switched from having a requirement that at least part of the employer contributions had to be in company stock to having no restrictions on investment choices for employer contributions next year. To isolate the effect of a specific change in the employer match policy on contribution allocation decisions over time, specifications (2) - (5) focus on firms that had no subsequent change in the match policy after the initial change during time t. It also includes the firms that had no change in fund options, even in year $t$. Thus, specification (5) measures how the fraction of contributions allocated to company stock has changed over the next five years for firms that either made no change in match policy or the group of firms that changed match policy during year $t$, but had no further change in match policy after year $t$. 


\begin{tabular}{|c|c|c|c|}
\hline \multicolumn{4}{|c|}{$\begin{array}{c}\text { Table 11: Regression of Share of Own Contributions in Company Stock } \\
\text { Upon Plan Characteristics, Firm Characteristics, and Past Firm Performance } \\
\text { (standard error in parentheses) } \\
\text { Dependent variable }= \\
\text { Employee Contributions in Company Stock / Total Employee Contributions }\end{array}$} \\
\hline & $1991-2000$ & $1991-2000$ & $1991-2000$ \\
\hline 1 / \# of options & $\begin{array}{c}.83 \\
(.08)\end{array}$ & $\begin{array}{c}.84 \\
(.11)\end{array}$ & $\begin{array}{c}.44 \\
(.05)\end{array}$ \\
\hline $\begin{array}{l}\text { Is this the first year company stock } \\
\text { is offered as an option? }\end{array}$ & $\begin{array}{l}-.09 \\
(.01)\end{array}$ & $\begin{array}{l}-.09 \\
(.01)\end{array}$ & $\begin{array}{l}-.028 \\
(.005)\end{array}$ \\
\hline $\begin{array}{c}\text { Is investment in } \\
\text { company stock limited? }\end{array}$ & $\begin{array}{l}-.07 \\
(.03)\end{array}$ & $\begin{array}{l}-.07 \\
(.03)\end{array}$ & - \\
\hline $\begin{array}{l}\text { Maximum fraction that } \\
\text { can be in company stock }\end{array}$ & $\begin{array}{l}-.10 \\
(.09)\end{array}$ & $\begin{array}{l}-.06 \\
(.11)\end{array}$ & $\begin{array}{l}.22 \\
(.14)\end{array}$ \\
\hline $\begin{array}{l}\text { Is part of employee contributions } \\
\text { required to be in company stock? }\end{array}$ & $\begin{array}{l}.19 \\
(.09)\end{array}$ & $\begin{array}{l}.17 \\
(.07)\end{array}$ & - \\
\hline $\begin{array}{l}\text { Minimum fraction that } \\
\text { must be in company stock }\end{array}$ & $\begin{array}{l}.33 \\
(.24)\end{array}$ & $\begin{array}{l}.38 \\
(.18)\end{array}$ & - \\
\hline $\begin{array}{l}\text { Is there an incentive to } \\
\text { invest in company stock? }\end{array}$ & $\begin{array}{l}.11 \\
(.06)\end{array}$ & $\begin{array}{l}.12 \\
(.06)\end{array}$ & $\begin{array}{l}.34 \\
(.06)\end{array}$ \\
\hline $\begin{array}{l}\text { Is part of the match required } \\
\text { to be in company stock? }\end{array}$ & $\begin{array}{l}.05 \\
(.01)\end{array}$ & $\begin{array}{l}.05 \\
(.01)\end{array}$ & $\begin{array}{l}.015 \\
.008)\end{array}$ \\
\hline $\begin{array}{l}\text { Is part of the match required } \\
\text { to NOT be in company stock? }\end{array}$ & $\begin{array}{l}-.034 \\
(.026) \\
\end{array}$ & $\begin{array}{l}-.027 \\
(.021) \\
\end{array}$ & $\begin{array}{l}-.075 \\
(.029) \\
\end{array}$ \\
\hline Stock return over past year & $\begin{aligned} .020 \\
(.005) \\
\end{aligned}$ & $\begin{array}{l}.020 \\
(.005) \\
\end{array}$ & \\
\hline Log (price beginning of year) & & & $\begin{array}{l}.028 \\
(.005)\end{array}$ \\
\hline $\begin{array}{l}\text { Standard deviation of } \\
\text { past stock returns }\end{array}$ & $\begin{array}{l}-.080 \\
(.032)\end{array}$ & $\begin{array}{l}-.059 \\
(.032)\end{array}$ & $\begin{array}{l}.004 \\
(.028)\end{array}$ \\
\hline Market-to-book ratio & $\begin{array}{l}.021 \\
(.004)\end{array}$ & $\begin{array}{l}.025 \\
(.005)\end{array}$ & $\begin{array}{l}.017 \\
(.004)\end{array}$ \\
\hline Log (assets) & $\begin{array}{l}.024 \\
(.003)\end{array}$ & $\begin{array}{l}.021 \\
(.004)\end{array}$ & $\begin{array}{l}.006 \\
(.006)\end{array}$ \\
\hline Constant & $\begin{array}{l}-.14 \\
(.03)\end{array}$ & - & - \\
\hline Year effects & No & Yes & No \\
\hline Industry effects & No & Yes & No \\
\hline Firm effects & No & No & Yes \\
\hline $\mathrm{R}^{2}$ & .341 & .362 & .188 within \\
\hline \# of observations & 2927 & 2927 & 2930 \\
\hline
\end{tabular}

All regression estimation allows for heteroskedasticity. The standard error calculation in the pooled crosssection regression allows for correlation across observations of the same firm as well. 


\begin{tabular}{|c|c|c|c|}
\hline \multirow{2}{*}{\multicolumn{4}{|c|}{$\begin{array}{l}\text { Table 12: Regression of Share of Own Contributions in Company Stock } \\
\text { on Alternative Measures of Past Firm Performance } \\
\text { (standard error in parentheses) } \\
\text { Dependent variable = } \\
\text { Employee Contributions in Company Stock / Total Employee Contributions }\end{array}$}} \\
\hline & & & \\
\hline & $1991-2000$ & $1991-2000$ & $1991-2000$ \\
\hline Stock return over past year & $\begin{array}{c}.012 \\
(.006)\end{array}$ & & \\
\hline Stock gain over past year & & $\begin{array}{c}.009 \\
(.006)\end{array}$ & \\
\hline Stock loss over past year & & $\begin{array}{l}-.008 \\
(.021)\end{array}$ & \\
\hline $\begin{array}{l}\text { Stock return over past year } \\
\text { relative to S\&P } 500 \text { (if }>0 \text { ) }\end{array}$ & & & $\begin{array}{l}.007 \\
(.006)\end{array}$ \\
\hline $\begin{array}{l}\text { Stock return over past year } \\
\text { relative to } S \& P 500(\text { if }<0)\end{array}$ & & & $\begin{array}{l}-.012 \\
(.016)\end{array}$ \\
\hline $\begin{array}{c}\text { Cumulative stock return } \\
\text { over past } 5 \text { years }\end{array}$ & $\begin{array}{c}.004 \\
(.004)\end{array}$ & & \\
\hline Stock gain over past 5 years & & $\begin{array}{c}.003 \\
(.003)\end{array}$ & \\
\hline Stock loss over past 5 years & & $\begin{array}{c}.089 \\
(.023)\end{array}$ & \\
\hline $\begin{array}{l}\text { Stock return over past } 5 \text { years } \\
\text { relative to } S \& P 500 \text { (if }>0 \text { ) }\end{array}$ & & & $\begin{array}{c}.002 \\
(.003)\end{array}$ \\
\hline $\begin{array}{l}\text { Stock return over past } 5 \text { years } \\
\text { relative to } S \& P 500 \text { (if < } 0 \text { ) }\end{array}$ & & & $\begin{array}{l}.053 \\
(.009)\end{array}$ \\
\hline Other variables & Yes & Yes & Yes \\
\hline $\mathrm{R}^{2}$ & .346 & .351 & .361 \\
\hline \# of observations & 2437 & 2437 & 2437 \\
\hline
\end{tabular}

Stock gain over past year and stock gain over past 5 years equal the respective return over that period if the return was positive, and are zero otherwise. Thus, these variables are either zero or positive.

Stock loss over past year and stock loss over past 5 years equal the respective return over that period if the return was negative, and are zero otherwise. Thus, these variables are either zero or negative. The stock return relative to the S\&P 500 index is broken up into two variables to allow for differential effects for firms that outperformed the S\&P 500 versus those that underperformed the S\&P 500. "Other variables" include all the other explanatory variables included in the Table 11 regressions. All regression estimation allows for heteroskedasticity. The standard error calculation in the pooled crosssection regressions allows for correlation across observations of the same firm as well. 


\begin{tabular}{|c|c|c|c|c|c|c|}
\hline \multirow[b]{2}{*}{$\begin{array}{c}\text { Stock return over } \\
\text { past year }\end{array}$} & \multicolumn{3}{|c|}{$\begin{array}{c}\text { Dependent Variable: } \\
1 / \text { \# options }\end{array}$} & \multicolumn{3}{|c|}{$\begin{array}{l}\text { Dep. Variable: All Match } \\
\text { Required in Company Stock? }\end{array}$} \\
\hline & & $\begin{array}{l}-.001 \\
(.002)\end{array}$ & & & $\begin{array}{l}.009 \\
(.016)\end{array}$ & \\
\hline $\begin{array}{l}\text { Stock return over } \\
\text { past } 5 \text { years }\end{array}$ & & $\begin{array}{l}.0003 \\
(.0004)\end{array}$ & & & $\begin{array}{l}-.009 \\
(.004)\end{array}$ & \\
\hline $\begin{array}{l}\text { Std. deviation } \\
\text { of stock returns }\end{array}$ & & $\begin{array}{l}-.009 \\
(.015)\end{array}$ & & & $\begin{array}{l}-.30 \\
(.18)\end{array}$ & \\
\hline $\begin{array}{l}\text { Market-to-book } \\
\text { ratio }\end{array}$ & $\begin{array}{l}-.001 \\
(.001)\end{array}$ & $\begin{array}{l}-.001 \\
(.002)\end{array}$ & $\begin{array}{l}-.001 \\
(.001) \\
\end{array}$ & $\begin{array}{l}-.005 \\
(.015) \\
\end{array}$ & $\begin{array}{l}.020 \\
(.022) \\
\end{array}$ & $\begin{array}{l}.003 \\
(.005) \\
\end{array}$ \\
\hline $\begin{array}{l}\text { Cash Flow / } \\
\text { Assets }\end{array}$ & $\begin{array}{l}-.006 \\
(.004)\end{array}$ & $\begin{array}{l}.002 \\
(.018)\end{array}$ & $\begin{array}{l}-.005 \\
(.004)\end{array}$ & $\begin{array}{l}.11 \\
(.14)\end{array}$ & $\begin{array}{l}.21 \\
(.24)\end{array}$ & $\begin{array}{l}-.09 \\
(.10)\end{array}$ \\
\hline Log (assets) & $\begin{array}{l}.003 \\
(.001)\end{array}$ & $\begin{array}{l}.003 \\
(.001) \\
\end{array}$ & $\begin{array}{l}-.002 \\
(.003) \\
\end{array}$ & $\begin{array}{c}.024 \\
(.010) \\
\end{array}$ & $\begin{array}{l}.007 \\
(.013) \\
\end{array}$ & $\begin{array}{l}0.001 \\
(.017) \\
\end{array}$ \\
\hline 1992 & $\begin{array}{l}-.04 \\
(.01)\end{array}$ & $\begin{array}{l}-.03 \\
(.01)\end{array}$ & $\begin{array}{l}-.04 \\
(.01)\end{array}$ & $\begin{array}{l}-.05 \\
(.06)\end{array}$ & $\begin{array}{l}-.07 \\
(.07)\end{array}$ & $\begin{array}{l}.04 \\
(.03)\end{array}$ \\
\hline 1993 & $\begin{array}{l}-.06 \\
(.01)\end{array}$ & $\begin{array}{l}-.06 \\
(.01)\end{array}$ & $\begin{array}{l}-.06 \\
(.01)\end{array}$ & $\begin{array}{l}-.08 \\
(.07)\end{array}$ & $\begin{array}{l}-.11 \\
(.07)\end{array}$ & $\begin{array}{l}.03 \\
(.03)\end{array}$ \\
\hline 1994 & $\begin{array}{l}-.09 \\
(.01)\end{array}$ & $\begin{array}{l}-.09 \\
(.01)\end{array}$ & $\begin{array}{l}-.09 \\
(.01)\end{array}$ & $\begin{array}{l}-.14 \\
(.07)\end{array}$ & $\begin{array}{l}-.17 \\
(.08)\end{array}$ & $\begin{array}{l}.03 \\
(.03)\end{array}$ \\
\hline 1995 & $\begin{array}{l}-.11 \\
(.01)\end{array}$ & $\begin{array}{l}-.11 \\
(.01)\end{array}$ & $\begin{array}{l}-.11 \\
(.01)\end{array}$ & $\begin{array}{l}-.18 \\
(.07)\end{array}$ & $\begin{array}{l}-.18 \\
(.08)\end{array}$ & $\begin{array}{l}.03 \\
(.03)\end{array}$ \\
\hline 1996 & $\begin{array}{l}-.13 \\
(.01)\end{array}$ & $\begin{array}{l}-.13 \\
(.01)\end{array}$ & $\begin{array}{l}-.12 \\
(.01)\end{array}$ & $\begin{array}{l}-.19 \\
(.07)\end{array}$ & $\begin{array}{l}-.20 \\
(.08)\end{array}$ & $\begin{array}{l}.02 \\
(.03)\end{array}$ \\
\hline 1997 & $\begin{array}{l}-.15 \\
(.01)\end{array}$ & $\begin{array}{l}-.14 \\
(.01)\end{array}$ & $\begin{array}{l}-.14 \\
(.01)\end{array}$ & $\begin{array}{l}-.22 \\
(.07)\end{array}$ & $\begin{array}{l}-.24 \\
(.08)\end{array}$ & $\begin{array}{c}.02 \\
(.03)\end{array}$ \\
\hline 1998 & $\begin{array}{c}-.16 \\
(.01)\end{array}$ & $\begin{array}{l}-.15 \\
(.01)\end{array}$ & $\begin{array}{l}-.15 \\
(.01)\end{array}$ & $\begin{array}{l}-.24 \\
(.07)\end{array}$ & $\begin{array}{l}-.25 \\
(.08)\end{array}$ & $\begin{array}{l}.01 \\
(.03)\end{array}$ \\
\hline 1999 & $\begin{array}{c}-.16 \\
(.01)\end{array}$ & $\begin{array}{l}.15 \\
(.01)\end{array}$ & $\begin{array}{l}.16 \\
(.01)\end{array}$ & $\begin{array}{l}.12 \\
(.09)\end{array}$ & $\begin{array}{l}-.14 \\
(.10)\end{array}$ & $\begin{array}{c}.02 \\
(.03)\end{array}$ \\
\hline 2000 & $\begin{array}{l}-.17 \\
(.01)\end{array}$ & $\begin{array}{l}-.17 \\
(.01)\end{array}$ & $\begin{array}{l}-.16 \\
(.01)\end{array}$ & $\begin{array}{c}.04 \\
(.10)\end{array}$ & $\begin{array}{l}-.04 \\
(.12)\end{array}$ & $\begin{array}{c}.04 \\
(.04)\end{array}$ \\
\hline Constant & $\begin{array}{c}.30 \\
(.01)\end{array}$ & $\begin{array}{c}.30 \\
(.02)\end{array}$ & - & $\begin{array}{c}.40 \\
(.11)\end{array}$ & $\begin{array}{c}.66 \\
(.16)\end{array}$ & - \\
\hline Firm effects & No & No & Yes & No & No & Yes \\
\hline $\mathrm{R}^{2}$ & .345 & .350 & $\begin{array}{c}.475 \\
\text { within }\end{array}$ & .029 & .034 & $\begin{array}{c}.007 \\
\text { within }\end{array}$ \\
\hline \# of observations & 3278 & 2437 & 3278 & 3073 & 2294 & 3073 \\
\hline
\end{tabular}

The match policy regressions are estimated using firm-year observations where the employer made contributions to the plan.

All regression estimation allows for heteroskedasticity. The standard error calculation in the pooled crosssection regressions allows for correlation across observations of the same firm as well. 


\begin{tabular}{|c|c|c|c|c|c|c|}
\hline \multicolumn{7}{|c|}{$\begin{array}{l}\text { Table 14: Dividend Policy and Employer Match Policy } \\
\text { (standard error of difference in parentheses) }\end{array}$} \\
\hline & \multicolumn{3}{|c|}{ Percent of firms that pay dividends } & \multicolumn{3}{|c|}{ Average dividend yield (percent) } \\
\hline & $\begin{array}{l}\text { Match all } \\
\text { required in } \\
\text { co. stock }\end{array}$ & $\begin{array}{c}\text { Match } \\
\text { not all in } \\
\text { co. stock }\end{array}$ & Difference & $\begin{array}{l}\text { Match all } \\
\text { required in } \\
\text { co. stock }\end{array}$ & $\begin{array}{l}\text { Match } \\
\text { not all in } \\
\text { co. stock }\end{array}$ & Difference \\
\hline 1993 & 78.0 & 67.8 & $\begin{array}{l}10.2 \\
(5.2)\end{array}$ & 2.20 & 1.86 & $\begin{array}{l}.33 \\
(.21)\end{array}$ \\
\hline 1994 & 72.8 & 60.6 & $\begin{array}{l}12.2 \\
(5.1)\end{array}$ & 2.30 & 1.66 & $\begin{array}{l}.63 \\
(.23)\end{array}$ \\
\hline 1995 & 68.8 & 58.6 & $\begin{array}{l}10.2 \\
(4.7)\end{array}$ & 1.83 & 1.30 & $\begin{array}{l}.53 \\
(.17)\end{array}$ \\
\hline 1996 & 67.7 & 55.1 & $\begin{array}{l}12.6 \\
(4.3)\end{array}$ & 1.72 & 1.32 & $\begin{array}{l}.39 \\
(.16)\end{array}$ \\
\hline 1997 & 66.5 & 55.4 & $\begin{array}{l}11.1 \\
(4.1)\end{array}$ & 1.46 & 1.09 & $\begin{array}{l}.36 \\
(.14)\end{array}$ \\
\hline 1998 & 65.3 & 52.2 & $\begin{array}{l}13.2 \\
(4.1)\end{array}$ & 1.69 & 1.14 & $\begin{array}{l}.55 \\
(.16)\end{array}$ \\
\hline $\begin{array}{l}1991- \\
2000\end{array}$ & 70.7 & 57.6 & $\begin{array}{l}13.1 \\
(3.4)\end{array}$ & 1.94 & 1.36 & $\begin{array}{l}.57 \\
(.14)\end{array}$ \\
\hline
\end{tabular}




\begin{tabular}{|c|c|c|c|c|}
\hline \multicolumn{5}{|c|}{$\begin{array}{l}\text { Table 15: Regression of Whether Employer Match is Required to be in } \\
\text { Company Stock Upon Firm Dividend Policy }\end{array}$} \\
\hline \multicolumn{5}{|c|}{ Dependent Variable: All Match Required in Company Stock? } \\
\hline Does the firm pay dividends? & $\begin{array}{l}.134 \\
(.035)\end{array}$ & $\begin{array}{l}.097 \\
(.040)\end{array}$ & & \\
\hline $\begin{array}{l}\text { Dividend yield } \\
\text { (div / price) }\end{array}$ & & & $\begin{array}{l}3.77 \\
(.95)\end{array}$ & $\begin{array}{r}2.89 \\
(1.05)\end{array}$ \\
\hline Other variables & No & Yes & No & Yes \\
\hline \# observations & 3182 & 3073 & 3182 & 3073 \\
\hline
\end{tabular}

Other variables include the market-to-book ratio, cash flow-to-assets, total assets, and year effects. The match policy regressions are estimated using firm-year observations where the employer made contributions to the plan.

Regressions estimated over pooled data 1991-2000. All regression estimation allows for heteroskedasticity. The standard error calculation in the pooled cross-section regressions allows for correlation across observations of the same firm as well. 
Table 16: Ratio of Employer Contributions to Employee Contributions (1991-2000 data pooled)

\begin{tabular}{|c|c|c|c|c|}
\hline & \multicolumn{3}{|c|}{} & \multicolumn{2}{c|}{$\begin{array}{c}\text { Firms that change from having a } \\
\text { match all in company stock to not } \\
\text { having any requirement** }\end{array}$} \\
\hline & Yes & No & $\begin{array}{c}\text { Before change }- \\
\text { with requirement }\end{array}$ & $\begin{array}{c}\text { After change }- \\
\text { no requirement }\end{array}$ \\
\hline $\begin{array}{c}\text { Mean* } \\
\text { (std. error) }\end{array}$ & .46 & .48 & .34 & .36 \\
\hline Median & $. .03)$ & $(.01)$ & $(.07)$ & $(.10)$ \\
\hline
\end{tabular}

* Weighted by the amount of employee contributions, the weighted average ratio of employer / employee contributions is .41 for firms that require the match to all be in company stock and .43 for firms that do not. ** There are 18 firms in the sample that change from having a match required to all be in company stock to either having a match with no requirement (13 firms) or eliminating the match entirely (5 firms) and have at least one full year of data pre- and post-change. The last two columns report the ratio of employer / employee contributions the year before the change and the year after the change for these 18 firms. 
Table 17a: Raw Stock Returns Following a Change in the Company Match Policy

Average raw stock return over period reported

[median reported in brackets]

\begin{tabular}{|c|c|c|c|c|}
\hline & $\begin{array}{c}\text { Return over } \\
\text { next year }\end{array}$ & $\begin{array}{c}\text { Return over } \\
\text { next two years }\end{array}$ & $\begin{array}{c}\text { Return next } \\
\text { year - return } \\
\text { past year }\end{array}$ & $\begin{array}{c}\text { Return next two } \\
\text { years - return } \\
\text { past two years }\end{array}$ \\
\hline $\begin{array}{c}\text { Switched } \\
\text { from choice } \\
\text { to all stock } \\
\text { (9 firms) }\end{array}$ & $7.0 \%$ & $36.0 \%$ & $-7.9 \%$ & $-8.9 \%$ \\
\hline $\begin{array}{c}\text { Switched } \\
\text { from all stock } \\
\text { to choice } \\
(10 \text { firms) }\end{array}$ & {$[-4.9]$} & {$[-10.5]$} & {$[-1.7]$} & {$[-59.5]$} \\
\hline
\end{tabular}

There are 19 firms in the sample that switch there match policy from offering a match required to all be in company stock to offering a match with employee investment choice for all of the match (or vice versa), note the exact date of the switch in the 11-k filing, and have returns on CRSP for at least two years before and two years after the switch.

Table 17b: Excess Stock Returns Following a Change in the Company Match Policy

Average excess stock return over period reported

[median reported in brackets]

\begin{tabular}{|c|c|c|c|c|}
\hline & $\begin{array}{c}\text { Return over } \\
\text { next year }\end{array}$ & $\begin{array}{c}\text { Return over } \\
\text { next two years }\end{array}$ & $\begin{array}{c}\text { Return next } \\
\text { year - return } \\
\text { past year }\end{array}$ & $\begin{array}{c}\text { Return next two } \\
\text { years - return } \\
\text { past two years }\end{array}$ \\
\hline $\begin{array}{c}\text { Switched } \\
\text { from choice } \\
\text { to all stock } \\
\text { (9 firms) }\end{array}$ & $-10.7 \%$ & $-2.1 \%$ & $-6.9 \%$ & $-14.6 \%$ \\
\hline $\begin{array}{c}\text { Switched } \\
\text { from all stock } \\
\text { to choice } \\
(10 \text { firms) }\end{array}$ & {$[-11.9]$} & {$[-27.6]$} & {$[6.8]$} & {$[-64.2]$} \\
\hline
\end{tabular}

Excess return is the raw stock return over the period less the return of the S\&P 500 index over the period. 
Figure 1: Mean Risk of Various Investments Reported by Participants (scale is 1 for "not risky at all" to 10 "extremely risky")

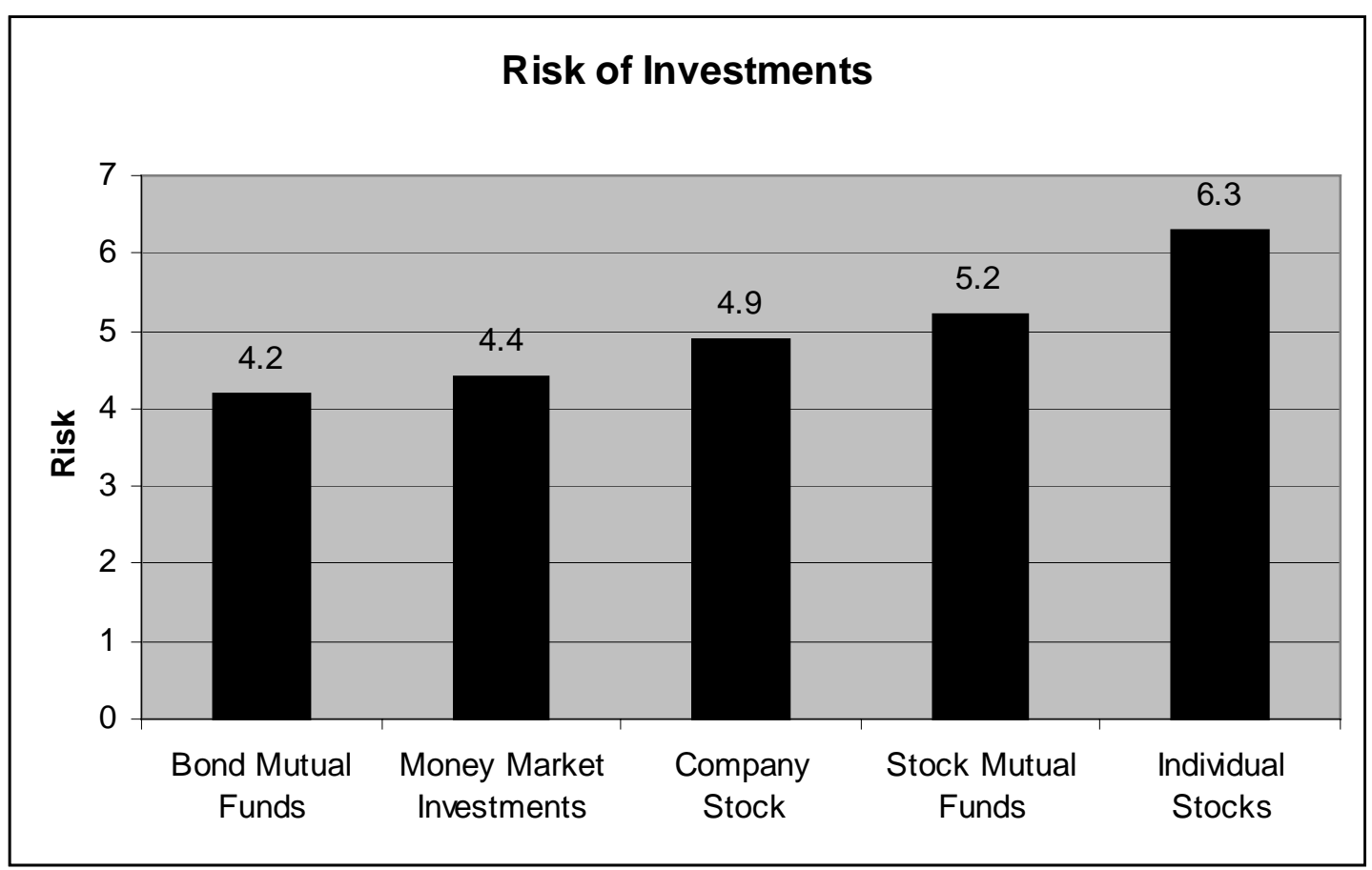

Based on a telephone survey of 500 participants in defined contribution plans conducted by Vanguard and reported in the January 2002 Vanguard Monitor. 
Figure 2: Average Return on Stock Portfolio Expected Over the Next Year vs. the Average Actual Return Received on Stock Portfolio Over the Past Year

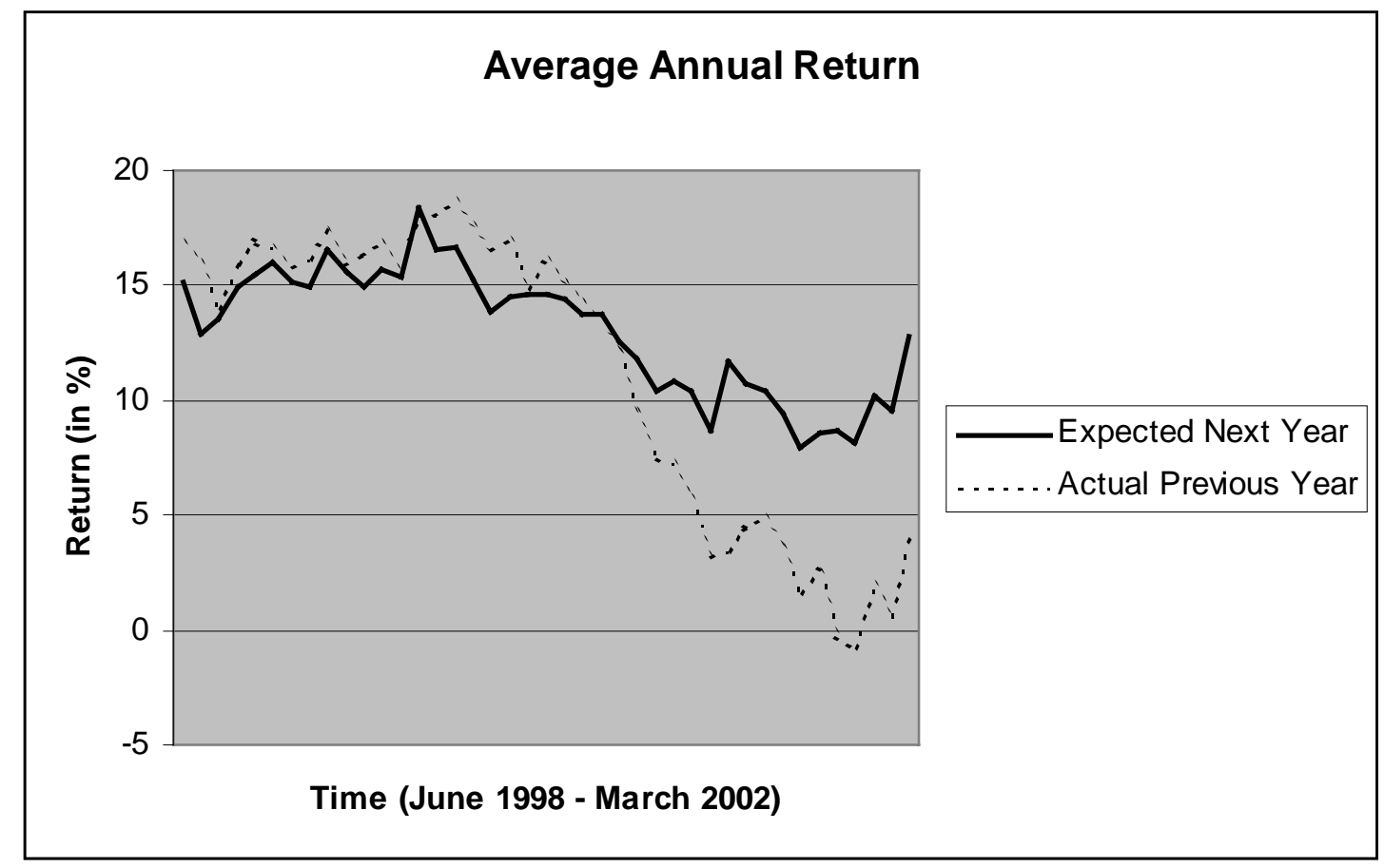

Figure 3: Median Return on Stock Portfolio Expected Over the Next Year vs. the Median Actual Return Received on Stock Portfolio Over the Past Year

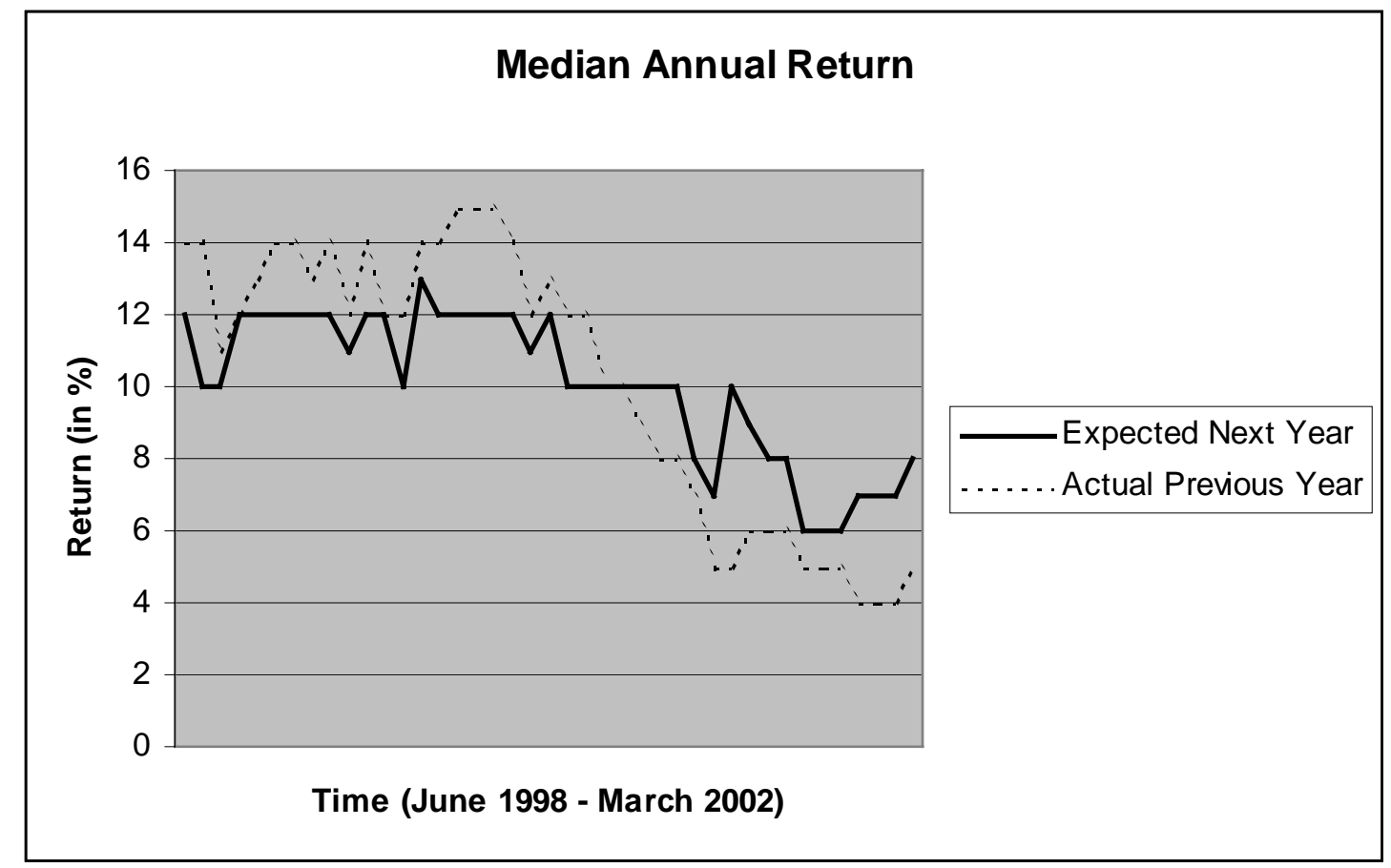

The average and median realized and expected returns are based on monthly telephone interviews with approximately 1000 investors aged 18+ conducted by the Gallup Organization for the UBS PaineWebber Index of Optimism. 
Figure 4: Fraction of Survey Respondents that Expect to Receive a

Return $<10 \%$ Over the Next Year vs. the Fraction of Survey

Respondents that Received a Return $<10 \%$ Over the Past Year

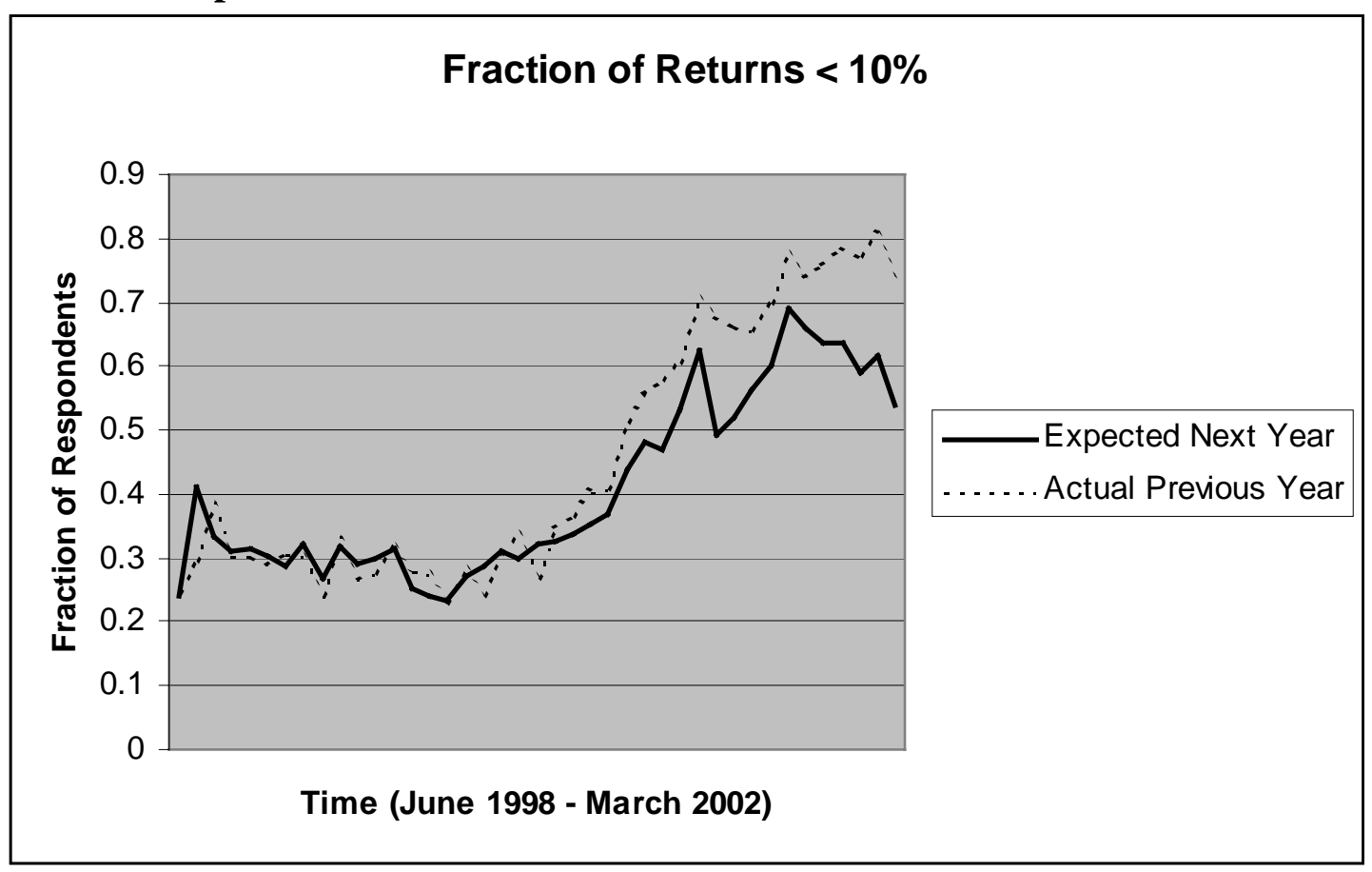

Figure 5: Fraction of Survey Respondents that Expect to Receive a

Return > 19\% Over the Next Year vs. the Fraction of Survey

Respondents that Received a Return > 19\% Over the Past Year

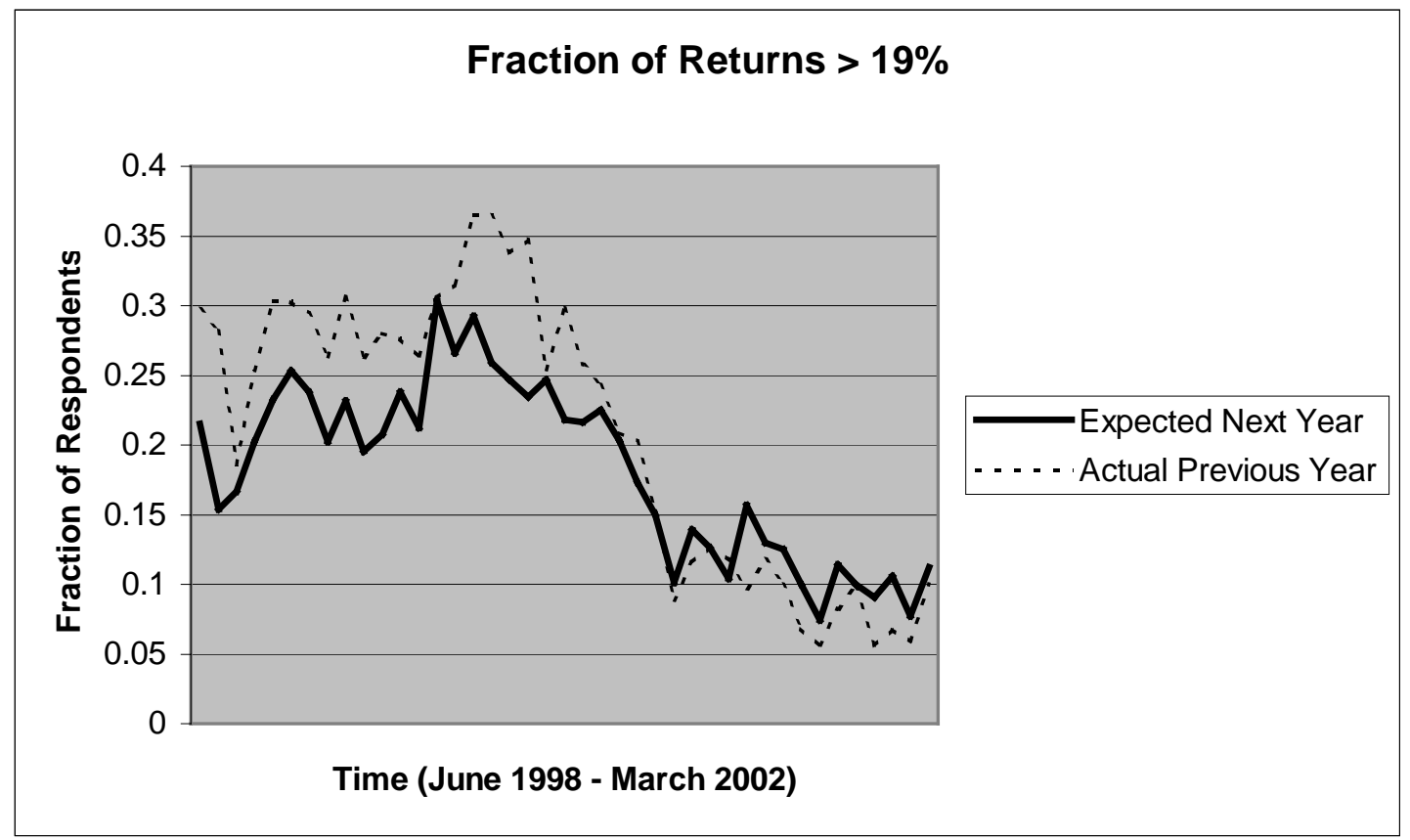

Based on monthly telephone interviews with approximately 1000 investors aged 18+ conducted by the Gallup Organization for the UBS PaineWebber Index of Optimism. 